\title{
Lipid-based Nanocarriers for siRNA Delivery: Challenges, Strategies and the Lessons Learned from the DODAX: MO Liposomal System
}

\author{
Ana C.N. Oliveira ${ }^{1,2}$, Joana Fernandes ${ }^{1}$, Anabela Gonçalves ${ }^{1}$, Andreia C. Gomes ${ }^{1}{ }^{*}$ and M.E.C.D. \\ Real Oliveira ${ }^{2, *}$
}

${ }^{1}$ CBMA (Center of Molecular and Environmental Biology), Department of Biology, University of Minho, Campus of Gualtar, 4710-057 Braga, Portugal; ${ }^{2}$ CFUM (Center of Physics), Department of Physics, University of Minho, Campus of Gualtar, 4710-057 Braga, Portugal

\begin{abstract}
The possibility of using the RNA interference (RNAi) mechanisms in gene therapy was one of the scientific breakthroughs of the last century. Despite the extraordinary therapeutic potential of this approach, the need for an efficient gene carrier is hampering the translation of the RNAi technology to the clinical setting. Although a diversity of nanocarriers has been described, liposomes continue to be one of the most attractive siRNA vehicles due to their relatively low toxicity, facilitated siRNA complexation, high transfection efficiency and enhanced pharmacokinetic properties.

This review focuses on RNAi as a therapeutic approach, the challenges to its application, namely the nucleic acids' delivery process, and current strategies to improve therapeutic efficacy. Additionally, lipid-based nanocarriers are described, and lessons learned from the relation between biophysical properties and biological performance of the dioctadecyldimethylammonium:monoolein (DODAX:MO) system are explored.

Liposomes show great potential as siRNA delivery systems, being safe nanocarriers to protect nucleic acids in circulation, extend their half-life time, target specific cells and reduce off-target effects. Nevertheless, several issues related to delivery must be overcome before RNAi therapies reach their full potential, namely target-cell specificity and endosomal escape. Understanding the relationship between biophysical properties and biological performance is an essential step in the gene therapy field.
\end{abstract}

A R T I C L E H IS T O R Y

Received: January 25, 2018

Revised: April 24, 2018

Accepted: June 28, 2018

DOI:

$10.2174 / 1389450119666180703145410$

Keywords: Cationic liposomes, monoolein, siRNA delivery, DODAB, DODAC, PEGylation.

\section{INTRODUCTION}

The discovery of RNA interference (RNAi) mechanisms has opened a world of new opportunities in the field of gene therapy, providing alternatives to the treatment of diseases for which there are no drugs available. Although mechanisms associated with RNAi are well established, this technology still faces important challenges before it can be an effective therapeutic alternative. The delivery of nucleic acid sequences constitutes one of the most important bottlenecks to RNAi therapeutic approaches, not only concerning stability and protection of the genetic material in physiological conditions, but also regarding the ability to target specific cells and release the therapeutic payload onto their cytoplasm. Several strategies have been explored to overcome each of these barriers, including PEGylation to provide

\footnotetext{
*Address correspondence to these authors at the Department of Biology, University of Minho, Campus of Gualtar, 4710-057 Braga, Portugal; Tel: +351 253 605311; Fax: +351 253 601511; E-mail: agomes@bio.uminho.pt and Department of Physics, University of Minho, Campus of Gualtar, 4710057 Braga, Portugal; Tel: +351 253 604325; Fax: +351 253 604061;

E-mail: beta@fisica.uminho.pt
}

stability in physiological conditions, incorporation of target molecules to potentiate active targeting, or inclusion of stimuli-responsive molecules to improve nucleic acids endosomal escape. This review describes RNAi as a therapeutic approach, as well as the challenges faced by it, namely the nucleic acids delivery process, together with current strategies to overcome some of these challenges. Liposomes are exploited as delivery systems due to their great potential as nanocarriers [1]. The influence of the physicochemical characteristics onto the biological performance of the nanosystem is elucidated by the example of a liposomal system composed by the cationic lipids dioctadecyldimethylammonium bromide or chloride (DODAB/DODAC) and the neutral lipid monoolein (MO).

\section{POTENTIAL OF RNA AS A GENE THERAPY TOOL}

RNAi is a natural post-transcriptional gene silencing mechanism, by which double-stranded RNAs (dsRNAs) modulate the expression of target RNAs, in a sequencespecific dependent manner. The first time an RNAi-type of phenomenon was reported in 1990 when Napoli and Jorgen- 
sen [2] obtained white petunias when trying to generate violet ones. The authors attributed this effect to the "cosuppressing" gene introduced into the cells. In 1992, a similar phenomenon was described for Neurospora crassa, when the introduction of homologous RNA sequences was reported to cause "quelling" of the targeted endogenous gene [3]. The description of the same type of mechanism in animals was made by Guo and Kemphues [4], that found that both sense and anti-sense strands resulted in the degradation of par-1 mRNA in the nematode Caenorhabditis elegans $(C$. elegans). It was only in 1998 that Fire and Mello provided a common explanation for the silencing of endogenous genes by "co-suppression, quelling and sense mRNA" [5]. When the authors showed, in C. elegans, that gene silencing was triggered by a dsRNA sequence, the term "RNA interference" was born. In 2001, the introduction of an artificial siRNA of 21 nucleotides (nt) was found to specifically block the expression of endogenous and heterologous genes in various mammalian cell lines [6], and in 2002 the therapeutic potential of siRNA was reinforced by McCaffrey et al., who demonstrated effective targeting of a sequence from hepatitis $\mathrm{C}$ virus by RNAi in vivo [7]. The importance of Fire and Mello's work for the comprehension of RNAi cellular mechanisms was recognized in 2006 with the Nobel Prize in Physiology or Medicine.

The RNAi mechanism is used in the context of gene therapy with the purpose to modulate the expression of genes involved in the development of diseases. An important advantage of this loss-of-function strategy is that, irrespective to its localization, virtually every single protein can be targeted. Furthermore, antisense RNAs do not lead to genome modifications, since they are not integrated in DNA, decreasing the safety concerns associated with therapeutic applications [8]. Frequent targets of this strategy are mutant transcripts [9], viral infections [10] and molecular effectors on cancer [11-13] (Table 1).

The potential of RNAi therapeutic approaches is demonstrated by the several clinical trials with siRNAs (Table 2).

\subsection{RNA Interference Mechanisms}

(Fig. 1) shows a representation of the small interfering RNA (siRNA) and micro RNA (miRNA) RNAi pathways. MicroRNAs are derived from the genome and function as regulators of endogenous genes $[37,38]$. The transcription of most miRNAs is typically performed by RNA polymerase II (RNA Pol II) into long primary transcripts (pri-miRNAs) of at least $1000 \mathrm{nt}$, with double-stranded hairpins and single stranded 5'- and 3'-terminal overhangs [37]. The miRNA lies within the pri-miRNA double-stranded stem. A nuclear microprocessor complex crops this pri-miRNA into 65-70 nt precursor miRNAs (pre-miRNA) that, after association with the transport facilitators Exportin-5 and RanGTP, are transported into the cytoplasm. The microprocessor complex, composed by Drosha and a protein cofactor with two doublestranded RNA binding domains (dsRBDs), is responsible for the cleavage of the loop of the hairpin, and excision of the pri-miRNA into pre-miRNA [39].

Once in the cytoplasm, pre-miRNA is further processed into a mature miRNA duplex of 21-25 nt in length by the
Dicer enzyme [40]. At this point, the siRNA and miRNA pathways converge, since siRNA is also processed from long dsRNAs by Dicer in the cytoplasm of the cells. Typically, 21-25 nt dsRNAs are generated by Dicer, with 2-base 3'overhangs, hydroxyl groups at the 3'-ends, and phosphate groups at the 5'-ends. This size is long enough to offer a sequence complexity sufficient for selective binding to a specific gene in the genome [40]. The sources of siRNA are long, linear, perfectly base-paired dsRNAs, endogenously produced or introduced directly into the cytoplasm. Additionally, siRNAs can also be directly introduced into the cytoplasm of the cells or expressed from gene expression cassettes embedded in DNA plasmids or viral vector genomes [41].

Once in the cytoplasm, the resulting double-stranded siRNA or miRNA is incorporated by the minimal RNA-induced silencing complex-loading complex (RISCloading complex) (Fig. 1) [37, 39, 41, 42], where the two strands of dsRNA unwind, the guide strand is loaded into AGO protein while the passenger strand is discarded, and a functional RISC is generated [37, 39, 41, 42]. RISC contains only the RNA antisense guide strand complementary to the target mRNA. The strand selection is dictated by the thermodynamic stability of the duplex ends: in the miRNA and siRNA pathways, the strand preferentially loaded into AGO protein has the less stable 5'-end [39]. The miRNA strand that associates with AGO proteins is called miRNA strand, while the other is discarded (miRNA*).

Finally, nucleotides $2-6$ of the guide strand, named seed sequence, initialize binding to the target mRNA. When perfect complementarity exists, the target mRNA molecule is cleaved in a very precise way: the phosphodiester linkage between the target nucleotides that are base-paired to siRNA residues 10 and 11 (counting from the 5'-end) is cleaved to generate products with 5'-monophosphate and 3'-hydroxyl termini [43]. The target dissociates after cleavage, and RISC is free to cleave additional mRNAs. While siRNA has perfect complementarity to the target mRNA, miRNA only binds imperfectly to mRNA, causing translational repression without endonucleolytic cleavage. This partial mismatched binding allows each miRNA to interact with many target mRNAs $[37,41]$.

\section{CHALLENGES IN RNA INTERFERENCE THERA- PIES - THE PROCESS OF SIRNA DELIVERY}

Despite the extensive knowledge about the RNAi mechanism, there are still several challenges that must be overcome for the safe and efficient application of this loss-of-function technology as a therapeutic strategy. RNAi is an essential mechanism of cell regulation, and minor alterations in RNAi machinery can have major consequences in cellular processes. The off-target effects associated with dsRNA introduction into cells can be divided into three classes: saturation of the endogenous RNAi machinery [44]; miRNA-like offtarget effects [45]; and induction of inflammatory responses due to activation of Toll-like receptors (TLRs) [46]. Other obstacles to RNAi as an effective therapeutic option include resistance to treatment [47], efficiency of the silencing effect compromised by the recognition of endosomal compartment [8, 48]. 
Table 1. Examples of targets used in RNAi-based approaches to cancer treatment.

\begin{tabular}{|c|c|c|c|}
\hline Pathway & Molecular Target & Cancer Model & References \\
\hline \multirow{2}{*}{ Cell cycle } & Cyclin B & Prostate & {$[14]$} \\
\hline & PLK1 & Breast & {$[15,16]$} \\
\hline \multirow{6}{*}{ Proliferation } & MAD2 & Colon & {$[17]$} \\
\hline & EPHA2 & Ovarian & {$[18]$} \\
\hline & AKT1 & Prostate & \multirow{3}{*}[19]{} \\
\hline & AKT2 & Prostate & \\
\hline & AKT3 & Prostate & \\
\hline & FAK & Ovarian & [20] \\
\hline \multirow{4}{*}{ Cell death and survival } & BCL-2 & Prostate & [21] \\
\hline & BCL-XL & Prostate & [22] \\
\hline & MCL-1 & Breast & [23] \\
\hline & Survivin & Prostate & [24] \\
\hline \multirow{5}{*}{ Angiogenesis } & VEGF & Prostate & {$[25,26]$} \\
\hline & PAR-1 & Melanoma & [27] \\
\hline & CD31 & Prostate & [28] \\
\hline & KLF-5 & Lung carcinoma & [29] \\
\hline & PLX1DC & Ovarian & [20] \\
\hline Cell senescence & TERT & Lewis lung tumor & {$[30]$} \\
\hline \multirow{5}{*}{ Oncogenes } & E6/E7 & Renal & [31] \\
\hline & EWS-FLI1 & Ewing sarcoma & [32] \\
\hline & c-RAF & Breast & [33] \\
\hline & $\mathrm{c}-\mathrm{MYC}$ & Melanoma & [34] \\
\hline & BCR-ABL & Chronic myeloid leukemia & [35] \\
\hline Resistance & P-gp & Breast & {$[36]$} \\
\hline
\end{tabular}

AKT1, 2, 3: protein kinase B 1, 2, 3; BCL-2: B-cell lymphoma 2; BCL-XL: B-cell lymphoma extra-large; BCR-ABL: breakpoint cluster region - abelson; CD31: cluster of differentiation 31; E6/E7: human papillomavirus oncoproteins E6 and E7; EPHA2: receptor of ephrins 2; EWS-FLI1: ewing's sarcoma-friend leukaemia virus integration 1; FAK: focal adhesion kinase; KLF-5: kruppel-like factor 5; MAD2: mitotic-arrest deficient 2; MCL-1: myeloid cell leukemia1; PAR-1: protease-activated receptor 1; P-gp: permeability glycoprotein; PLK1: Polo-like kinase 1; PLX1DC: plexin domain containing 1; TERT: telomerase reverse transcriptase; VEGF: vascular endothelium growth factor.

The physicochemical properties of siRNA duplexes, namely large weight and size, high hydrophilicity and negative charge, restrict the binding to cellular membranes and do not allow naked siRNAs to enter cells by passive diffusion mechanisms [49]. Thus, endocytosis is the major route of siRNA internalization, with endosomal entrapment and lysosomal degradation important barriers for its therapeutic use. Even when siRNA escapes from endosomes, the viscosity of the cytoplasm and the presence of organelles are still obstacles for its loading into the RISC complex. Inherent physicochemical properties of nucleic acids also imply that naked siRNA is quickly degraded by serum endonucleases [50], easily filtered from the glomerulus and rapidly excreted by the kidneys, resulting in a half-life of few minutes in plasma $[45,51]$. Extravasation from blood vessels to target tissues constitutes another challenge because in most tissues capillary vessel walls are impermeable to large nucleic acids. Some exceptions are tumors or inflamed tissues, where blood vessels are leaky. Furthermore, the dense network of polysaccharides and fibrous proteins of the extracellular matrix limits migration and access to target cells.

\section{DEVELOPMENTS IN NANOCARRIERS FOR SIRNA DELIVERY}

The targeted delivery of genetic material at controlled rates is a very attractive method, and has been strongly pursued, given the importance to improve safety and efficacy. The ideal delivery method should promote high transfection efficiency, low cell toxicity, minimal effects on physiology and be reproducible [52]. 
Table 2. Clinical trials of siRNA-based therapeutics. Details of each trial can be found on www.clinicaltrials.gov.

\begin{tabular}{|c|c|c|c|c|c|c|}
\hline Target & Disease & siRNA & Route & Phase & Sponsor & Start-end \\
\hline VEGF & Macular degeneration & Bevasiranib (Cand5) & IVT & $\mathrm{I} *$ & OPKO Health, Inc & 2004-07 \\
\hline VEGF & Diabetic macular edema & Bevasiranib (Cand5) & IVT & II * & OPKO Health, Inc & $2006-07$ \\
\hline VEGF & Macular degeneration & Bevasiranib (Cand5) & IVT & II * & OPKO Health, Inc & $2006-07$ \\
\hline VEGF & AMD & Bevasiranib (Cand5) & IVT & III $* *$ & OPKO Health, Inc & 2007-09 \\
\hline VEGF & AMD & Bevasiranib (Cand5) & IVT & $\begin{array}{r}\text { III } \\
\text { wd. }\end{array}$ & OPKO Health, Inc & Nov 2009- \\
\hline VEGFR1 & AMD & $\begin{array}{l}\text { AGB2 } 11745 \text { (siRNA- } \\
027)\end{array}$ & IVT & $\mathrm{I} / \mathrm{II} *$ & $\begin{array}{l}\text { Allergan siRNA Therap. } \\
\text { Inc. }\end{array}$ & 2004-07 \\
\hline VEGFR1 & Choroidal neovascularization & $\begin{array}{l}\text { AGB2 } 11745 \text { (siRNA- } \\
027)\end{array}$ & IVT & II $* *$ & $\begin{array}{l}\text { Allergan siRNA Therap. } \\
\text { Inc. }\end{array}$ & 2007-09 \\
\hline RTP801 & AMD & PF-04523655 (PF-655) & IVT & $\mathrm{I} *$ & Quark Pharma & $2007-09$ \\
\hline RTP801 & $\begin{array}{l}\text { Diabetic retinopathy, Diabetes } \\
\text { complications }\end{array}$ & PF-04523655 (PF-655) & IVT & II $* *$ & Quark Pharma & $2008-10$ \\
\hline RTP801 & $\begin{array}{c}\text { Choroidal neovascularization, } \\
\text { Diabetic retinopathy }\end{array}$ & PF-04523655 (PF-655) & IVT & II * & Quark Pharma & 2009-11 \\
\hline RTP801 & Diabetic macular edema & PF-04523655 (PF-655) & IVT & II * & Quark Pharma & $2012-13$ \\
\hline RSV-N gene & $\begin{array}{c}\text { Respiratory syncytial virus infec- } \\
\text { tions }\end{array}$ & ALN-RSV-01 & $\mathrm{NN}$ & II * & Alnylam Pharma & $\begin{array}{l}2007 \text { Jul- } \\
\text { Nov }\end{array}$ \\
\hline RSV-N gene & $\begin{array}{c}\text { Respiratory syncytial virus infec- } \\
\text { tions }\end{array}$ & ALN-RSV-01 & $\mathrm{NN}$ & II * & Alnylam Pharma & 2008-09 \\
\hline RSV-N gene & $\begin{array}{c}\text { Respiratory syncytial virus infec- } \\
\text { tions }\end{array}$ & ALN-RSV-01 & $\mathrm{NN}$ & $\mathrm{IIb} *$ & Alnylam Pharma & $2010-12$ \\
\hline P53 & $\begin{array}{c}\text { Injury of kidney, Acute renal fail- } \\
\text { ure }\end{array}$ & I5NP (QP1-1002) & IV & I * & Quark Pharma & $2007-10$ \\
\hline P53 & $\begin{array}{c}\text { Injury of kidney, Acute renal fail- } \\
\text { ure }\end{array}$ & I5NP (QP1-1002) & IV & $\mathrm{I} * *$ & Quark Pharma & $\begin{array}{c}2008- \\
2010\end{array}$ \\
\hline P53 & $\begin{array}{c}\text { Delayed graft function, Other } \\
\text { complications of kidney transplant }\end{array}$ & I5NP (QP1-1002) & IV & $\mathrm{I} / \mathrm{II} *$ & Quark Pharma & $2008-14$ \\
\hline K6A N171K & Pachyonychia congenita & TD101 & I.I. & I * & $\begin{array}{c}\text { Pachyonychia Congenital } \\
\text { Project }\end{array}$ & $\begin{array}{l}2008 \text { Jan- } \\
\text { Aug }\end{array}$ \\
\hline RRM2 & Solid tumors & CALAA-01 & IV & $\mathrm{I} * *$ & Calando Pharma & $2008-12$ \\
\hline KSP and VEGF & $\begin{array}{c}\text { Advanced solid tumors with liver } \\
\text { involvement }\end{array}$ & ALN-VSP02 & IV & $\mathrm{I} *$ & Alnylam Pharma & 2009-11 \\
\hline KSP and VEGF & $\begin{array}{c}\text { Advanced solid tumors with liver } \\
\text { involvement }\end{array}$ & ALN-VSP02 & IV & I * & Alnylam Pharma & $2010-12$ \\
\hline Apo B & Hypercholesterolemia & $\begin{array}{c}\text { PRO-040201 (TKM- } \\
\text { ApoB) }\end{array}$ & IV & $\mathrm{I} * *$ & $\begin{array}{l}\text { Arbutus Biopharma } \\
\text { (ABUS) }\end{array}$ & $2009-10$ \\
\hline PKN3 & Advanced solid tumors & Atu027 & IV & I * & Silence Therapeutics & $2009-12$ \\
\hline PKN3 & Pancreatic ductal carcinoma & Atu027 & IV & $\mathrm{I} / \mathrm{II} *$ & $\mathrm{GmbH}$ & $2013-16$ \\
\hline B2-AR & $\begin{array}{c}\text { Ocular hypertension, Open-angle } \\
\text { glaucoma }\end{array}$ & $\begin{array}{l}\text { SYL040012 } \\
\text { (Bamosiran) }\end{array}$ & Opht. & $\mathrm{I} *$ & Sylentis, S.A. & $2009-10$ \\
\hline
\end{tabular}

(Table 2) contd.... 


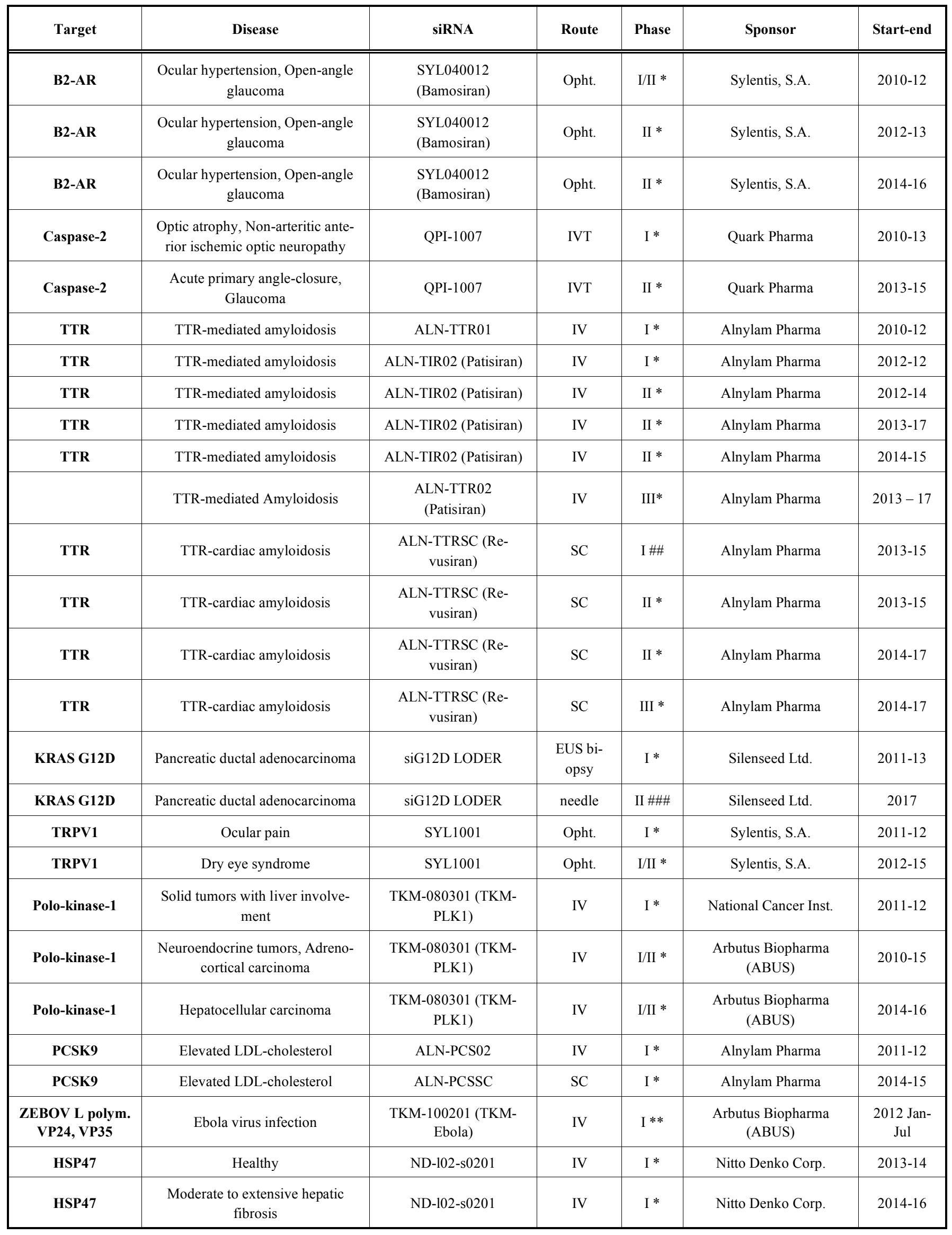




\begin{tabular}{|c|c|c|c|c|c|c|}
\hline Target & Disease & siRNA & Route & Phase & Sponsor & Start-end \\
\hline HSP47 & Ebola virus infection & TKM-100802 & IV & $\mathrm{I} * *$ & $\begin{array}{c}\text { Arbutus Biopharma } \\
\text { (ABUS) }\end{array}$ & 2014- 15 \\
\hline AT & Hemophilia A, Hemophilia B & ALN-AT3SC & $\mathrm{SC}$ & $\mathrm{I} *$ & Alnylam Pharma & $2014-17$ \\
\hline AT & Hemophilia A, Hemophilia B & ALN-AT3SC & $\mathrm{SC}$ & $\mathrm{I} / \mathrm{II} \#$ & Alnylam Pharma & 2015 \\
\hline \multirow[t]{2}{*}{$\begin{array}{l}\text { E3 ubiquitin } \\
\text { ligase Cbl-b }\end{array}$} & $\begin{array}{c}\text { Melanoma, Pancreatic cancer, } \\
\text { Renal cell cancer }\end{array}$ & APN401 & IV & I* & Wake Forest Univ. & $2014-16$ \\
\hline & $\begin{array}{l}\text { Pancreatic Cancer, Colorectal } \\
\text { Cancer, Solid tumors }\end{array}$ & APN401. & IV & I \#\# & Wake Forest Univ. & 2017 \\
\hline DCR-MYC & Hepatocellular carcinoma & MYC & IV & $\mathrm{I} / \mathrm{II} \# \#$ & Dicerna Pharma & 2014-16 \\
\hline DCR-MYC & $\begin{array}{c}\text { Solid tumors, Multiple myeloma, } \\
\text { Non-Hodgkin lymphoma }\end{array}$ & MYC & IV & I \#\# & Dicerna Pharma & $2014-15$ \\
\hline $\begin{array}{l}\text { siRNA-EphA2- } \\
\text { DOPC }\end{array}$ & Advanced cancers & EphA2 & IV & I \#\# & $\begin{array}{l}\text { MD Anderson Cancer } \\
\text { Center }\end{array}$ & 2015 \\
\hline TNFR:Fc & Rheumatoid Arthritis & $\operatorname{tg} \mathrm{AAC} 94$ & IA & $I^{*}$ & $\begin{array}{l}\text { Targeted Genetics Corpo- } \\
\text { ration }\end{array}$ & 2004-2005 \\
\hline hIFN-b & Rheumatoid Arthritis & ART-I02 & IA & $\mathrm{I} \# \#$ & Arthrogen & 2018 \\
\hline GDNF & Parkinson's Disease & /AAV2-GDNF & IC & $\mathrm{I} \#$ & $\begin{array}{l}\text { National Institute of Neu- } \\
\text { rological Disorders and } \\
\text { Stroke (NINDS) }\end{array}$ & 2012 \\
\hline NTN & Parkinson's Disease & CERE-120: AAV2-NTN & IC & $I^{*}$ & Ceregene & $2005-2007$ \\
\hline NRTN & Idiopathic Parkinson's Disease & CERE-120 & IC & $\mathrm{I} / \mathrm{II} \#$ & Sangamo Therapeutics & 2009 \\
\hline NRTN & Parkinson's Disease & CERE-120 & IC & II* & Ceregene & 2006-2008 \\
\hline AADC & Parkinson's Disease & VY-AADC01 & IC & $\mathrm{I} \#$ & Voyager Therapeutics & 2013 \\
\hline AADC & Parkinson's Disease & $\begin{array}{l}\text { Cohort1 } \\
\text { Cohort2 }\end{array}$ & IC & $\mathrm{I} / \mathrm{II} \# \#$ & Jichi Medical University & 2015 \\
\hline CLN2 & $\begin{array}{c}\text { Batten Disease } \\
\text { Late Infantile Neuronal Ceroid } \\
\text { Lipofuscinosis }\end{array}$ & AAV2CUhCLN2 & IC & $\mathrm{I} \#$ & $\begin{array}{l}\text { Weill Medical College of } \\
\text { Cornell University }\end{array}$ & 2004 \\
\hline CLN2 & $\begin{array}{c}\text { Batten Disease } \\
\text { Late Infantile Neuronal Ceroid } \\
\text { Lipofuscinosis }\end{array}$ & AAVrh.10CUCLN2 & IC & $\mathrm{I} / \mathrm{II} \#$ & $\begin{array}{l}\text { Weill Medical College of } \\
\text { Cornell University }\end{array}$ & 2010 \\
\hline CLN2 & $\begin{array}{c}\text { Batten Disease } \\
\text { Late Infantile Neuronal Ceroid } \\
\text { Lipofuscinosis }\end{array}$ & AAVrh.10CUhCLN2 & IC & $\mathrm{I} \#$ & $\begin{array}{l}\text { Weill Medical College of } \\
\text { Cornell University }\end{array}$ & 2010 \\
\hline NGF & Alzheimer's Disease & CERE-110 & IC & $I^{*}$ & Ceregene & 2004-2010 \\
\hline CFTR & Cystic Fibrosis & $\begin{array}{l}\text { Adeno-associated virus- } \\
\text { CFTR vector }\end{array}$ & $\mathrm{NN}$ & $I^{*}$ & $\begin{array}{l}\text { National Institute of Dia- } \\
\text { betes and Digestive and } \\
\text { Kidney Diseases }\end{array}$ & 1999-2002 \\
\hline RPE65 & $\begin{array}{l}\text { Leber Congenital Amaurosis } \\
\text { (LCA) }\end{array}$ & AAV2-hRPE65v2 & Opht & $\mathrm{I} \#$ & Spark Therapeutics & 2007 \\
\hline RPE65 & $\begin{array}{l}\text { Leber Congenital Amaurosis } \\
\text { (LCA) }\end{array}$ & AAV2-hRPE65v2 & Opht & I/II \# & Spark Therapeutics & 2010 \\
\hline RPE65 & $\begin{array}{l}\text { Leber Congenital Amaurosis } \\
\text { (LCA) }\end{array}$ & AAV2-hRPE65v2 & Opht & III\# & Spark Therapeutics & 2012 \\
\hline
\end{tabular}




\begin{tabular}{|c|c|c|c|c|c|c|}
\hline Target & Disease & siRNA & Route & Phase & Sponsor & Start-end \\
\hline GAA & Pompe Disease & rAAV1-CMV-GAA & IM & $\mathrm{I} / \mathrm{II}{ }^{*}$ & University of Florida & 2010-2015 \\
\hline GAA & $\begin{array}{l}\text { Late-Onset Pompe Disease } \\
\text { (LOPD) }\end{array}$ & rAAV9-DES-hGAA & IM & I\#\# & University of Florida & 2017 \\
\hline SMN & Spinal Muscular Atrophy Type 1 & AVXS-101 & IV & $I^{*}$ & AveXis, Inc. & 2014 \\
\hline SMN & Spinal Muscular Atrophy Type 1 & AVXS-101 & IV & III\#\# & AveXis, Inc. & 2017 \\
\hline SMN & Spinal Muscular Atrophy & AVXS-101 & IT & I\#\# & AveXis, Inc. & 2017 \\
\hline SMN & Spinal Muscular Atrophy & AVXS-101 & IV & III\#\#\# & AveXis, Inc. & 2018 may \\
\hline FIX & Hemophilia B & AAV8-hFIX19 & IV & $\mathrm{I}^{* *}$ & Spark Therapeutics & $\begin{array}{c}2012- \\
2016\end{array}$ \\
\hline FIX & Hemophilia B & $\begin{array}{l}\text { AAV5-hFIXco-Padua } \\
\text { (AMT-061) }\end{array}$ & IV & II\#\#\# & UniQure Biopharma B.V. & 2018 \\
\hline SGSH & $\begin{array}{c}\text { Mucopolysaccharidosis Type } 3 \text { A } \\
\text { Sanfilippo Syndrome }\end{array}$ & scAAV9.U1a.hSGSH & IV & I/II\#\# & Abeona Therapeutics, Inc & 2016 \\
\hline NAGLU & $\begin{array}{c}\text { Mucopolysaccharidosis (MPS) } \\
\text { IIIB }\end{array}$ & rAAV9.CMV.hNAGLU & IV & I/II\#\# & Kevin Flanigan & 2017 \\
\hline NAGLU & Sanfilippo Syndrome B & rAAV2/5-hNAGLU & I.I & $\mathrm{I} / \mathrm{II} \# \#$ & UniQure Biopharma B.V. & 2013 \\
\hline IDS & Mucopolysaccharidosis II & SB-913 & IV & I\#\# & Sangamo Therapeutics & 2017 \\
\hline IDUA & Mucopolysaccharidosis I & SB-318 & IV & I\#\# & Sangamo Therapeutics & 2017 \\
\hline ARSA & Metachromatic Leukodystrophy & AAVrh.10cuARSA & I.I & $\mathrm{I} / \mathrm{II} \#$ & $\begin{array}{c}\text { Institut National de la } \\
\text { Santé Et de la Recherche } \\
\text { Médicale, France }\end{array}$ & 2013 \\
\hline GAN & Giant Axonal Neuropathy & scAAV9/JeT-GAN & IT & I\#\# & $\begin{array}{l}\text { National Institute of Neu- } \\
\text { rological Disorders and } \\
\text { Stroke (NINDS) }\end{array}$ & 2015 \\
\hline CLN6 & Batten Disease & scAVV9.CB.CLN6 & IT & I/II\#\# & $\begin{array}{c}\text { Nationwide Children's } \\
\text { Hospital }\end{array}$ & 2016 \\
\hline
\end{tabular}

AMD - age-related macular degeneration; AT - antithrombin; $\beta 2$-AR - $\beta 2$ adrenergic receptor; EUS - endoscopic ultrasound; K6A N171K - keratin 6AN171K mutant; KRASG12D K-rasG12D mutant; KSP - kinesin spindle protein; LODER - local drug eluter; RRM2 - M2 subunit of ribonucleotide reductase; PCSK9 - proprotein convertase subtilisin/kexin type 9; PKN3 - protein kinase N3; RSVN gene - respiratory syncytial virus nucleocapsid gene; TTR - transthyretin; VEGF - vascular endothelial growth factor; VEGFR1 - vascular endothelial growth factor receptor 1; VP24: viral protein 24; VP35 - viral protein 35; ZEBOV L polym. - ZEBOV L polymerase. * - completed; ** - terminated; *** - suspended; \# active; \#\# - recruiting; \#\#\# - not yet recruiting; IVT - intravitreal; IV - intravenous injection; IT - intrathecal administration, IM- intramuscular; IA- intra-articular injection; IC Intracranial; Opht. - ophtalmic administration;II.-intralesional injection; $\mathrm{NN}$ - nasal nebulization; wd - withdrawn.

Significant advances have been made in the development of efficient nanocarriers, such as siRNA conjugates, inorganic materials polymers and cationic lipids for siRNA delivery (Table 3).

These systems can be categorized into viral carriers (viruses and bacteria) and non-viral carriers (polymers and cationic lipids) produced by physical methods, chemical or biological methods $[52,53]$. (Table 4) shows some advantages and disadvantages of viral and non-viral gene therapy vectors.

DNA-based expression cassettes that express short hairpin RNA (shRNA) are usually delivered to target cells ex vivo by viruses and bacteria, and these modified cells are then reinfused back into the patient [54]. Viral systems provide very efficient delivery and transfection to the intended target, however, they have several drawbacks, such as the potential to generate a severe immune response, as has been demonstrated in a number of non-human models and human trials. They are also limited in the size of a plasmid that they can encapsulate and by possible storage time $[55,56]$.

Another kind of siRNA carriers, widely used in therapeutics and biomedical engineering, are inorganic nanoparticles $[68,69]$. Their attractive physicochemical properties such as: good stability and physical strength, high purity, reproducible and tunable size and morphology, and ease for surface modification, make them good candidates for siRNAs delivery [70]. In fact, recent investigations revealed that several nanomaterials are intrinsically therapeutic, since they, not only can passively interact with cells but can also actively mediate molecular processes to regulate cell functions [71]. For instance, gold nanoparticles were shown to be antiangiogenic and with antitumor properties that interfere with cellular processes [69]. Characteristic inorganic nanoparticles are metals, metal oxides and carbon material and 


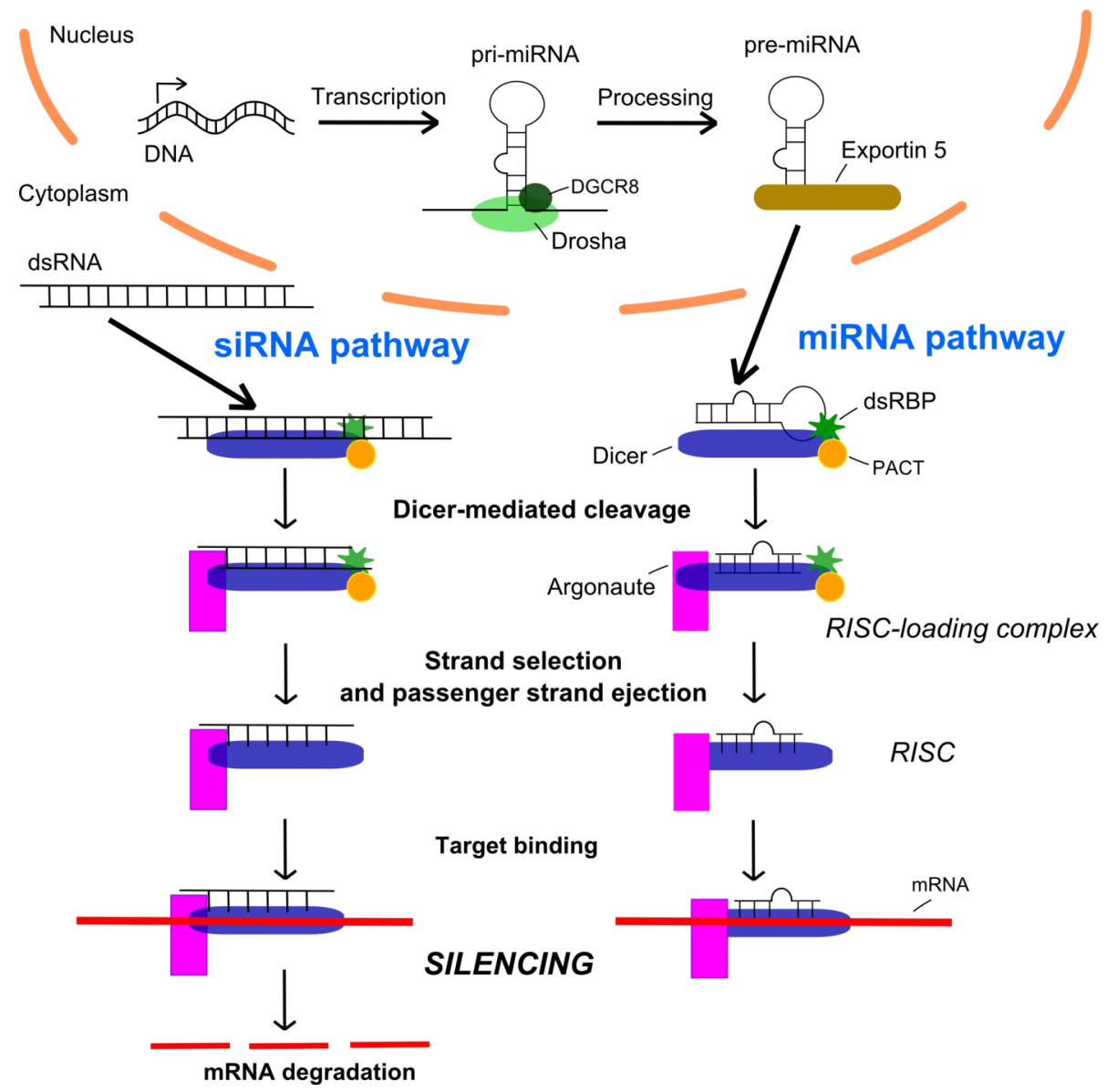

Fig. (1). Schematic representation of RNA interference mechanisms.

magnetic nanoparticles - SPIONS (Super-Paramagnetic Iron Oxide Nanoparticles). Gold nanoparticles have unique chemical and physical properties like low cytotoxicity, ease of synthesis, tunable size and morphology, ready functionalization and strong optical absorption that make them a useful scaffold for efficient recognition and delivery of biomolecules [72]. The synthesis of iron oxide nanoparticles has been intensively developed not only for its fundamental scientific interest but also for its many technological applications, such as targeted drug delivery, magnetic resonance imaging (MRI), magnetic hyperthermia and thermoablation, bioseparation, and biosensing. However, control over the shape and size distribution of magnetic iron oxide nanoparticles remains a challenge, and the different formation mechanisms of iron oxides under different conditions still need to be investigated [73]. Carbon nanotubes (CNTs) exhibit incomparable physical, mechanical and chemical properties, such as: strength, thermal conductivity, mechanical, and electrical properties. Also, could be used as additives to various structural materials [74]. Although these systems have great advantages for biomedical use, there are several concerns regarding their therapeutic use due to documented toxicity $[75,76]$.

Polymeric nanoparticles are solid, biodegradable, colloidal systems that can be classified into two major categories, natural polymers [cyclodextrin, chitosan, and atelocollagen] and synthetic polymers [polyethyleneimine (PEI), poly(dllactide-co-glycolide) (PLGA), and dendrimers]. These sys- tems have been demonstrated to provide effective and efficient siRNA delivery in vitro and in vivo. However, some studies have reported inconsistent results due to discrepancies between experiments, therefore PLGA could not be applied efficiently in siRNA delivery due to the lower electrostatic interaction between PLGA and siRNA leading to less efficient endosomal escape and release of siRNA and PEI complexes have been associated with significant toxicity issues limiting their broad use in clinical trials [77].

Future studies must focus on the in vivo safety profiles of the different delivery systems, including undesirable immune stimulation and cytotoxicity.

Lipid-based nanocarriers will be addressed in detail as they are to be focused in this review.

\subsection{Lipid-based Nanocarriers for siRNA Delivery}

Liposomes were first described by Bangham in the mid60s [78], and during the 70s the idea that they could entrap drugs and be used as drug delivery systems was further established by Gregoriadis [79]. Liposomes are composed by amphiphilic molecules that, when in aqueous solution and above the critical vesicle concentration (CVC), spontaneously self-assemble into one or multiple lipid bilayers, capable of entrapping hydrophilic substances in the inner aqueous compartments, and lipophilic compounds within the lipid layers. 
Table 3. Example of nanocarriers used for siRNA delivery.

\begin{tabular}{|c|c|}
\hline \multirow{4}{*}{ Type of System } & Example \\
\hline \hline \multirow{4}{*}{ siRNA conjugates } & Cholesterol [57] \\
\cline { 2 - 2 } & Cell-penetrating peptides (CPPs) [59] \\
\cline { 2 - 2 } & Poly(ethylene glycol) (PEG) [60] \\
\cline { 2 - 2 } Inorganic materials & Aptamers [61] \\
\cline { 2 - 2 } & Gold [62] \\
\cline { 2 - 2 } & Iron Oxide [63] \\
\hline \multirow{3}{*}{$\begin{array}{c}\text { Polymer-based } \\
\text { nanocarriers }\end{array}$} & Carbon nanotubes (CNTs) [64] \\
\cline { 2 - 2 } & Poly(ethyleneimine) (PEI) [60] \\
\cline { 2 - 2 } & Ch-L-lactide-co-glycolide (PLGA) [65] \\
\cline { 2 - 2 } & Chitosan [66] \\
\hline \multirow{3}{*}{$\begin{array}{c}\text { Lipid-based } \\
\text { nanocarriers }\end{array}$} & Dendrimers [67] \\
\cline { 2 - 2 } & Liposomes [13] \\
\hline
\end{tabular}

As non-viral vectors, liposomes have unique advantages, including high encapsulation efficiency, low toxicity and drug/genetic material protection against degradation factors. These vectors also reduce tissue irritation, uniformly deposit active drugs in situ and are biodegradable and nonimmunogenic [80]. Additionally, the liposomal membrane is com- posed of natural and/or synthetic lipids which are relatively biocompatible [81]. These systems have been used in the delivery of nucleic acids since the pioneering study of Felgner and colleagues, in 1987, describing the ability of the cationic lipid DOTMA (N-[1-(2,3-dioleyloxy)propyl]$\mathrm{N}, \mathrm{N}, \mathrm{N}$-trimethlyl ammonium chloride) to deliver DNA to the COS-7 cell line [82]. Cationic liposomes are used frequently for non-viral gene delivery due to their positive charge, as they interact electrostatically with the negative charges of nucleic acid phosphate groups, resulting in a nano-complex where the genetic material is entrapped - a process that leads to the formation of lipoplexes [83]. Also, it facilitates interactions with the negatively charged components of cell membranes, together with a good tolerability, high transfection activity and good pharmacokinetic properties. Cationic lipids used for gene therapy are composed of three basic domains: a positively charged headgroup, a hydrophobic chain, and a linker which joins the polar and non-polar regions. The nature of the cationic headgroup influences the ability to condense and protect nucleic acids, the cytotoxicity associated with the liposomes, and the overall transfection efficiency [84]. The influence of the hydrophobic chain on toxicity has not yet been adequately addressed but it is known that the hydrophobic lipid anchor helps to maintain the selfaggregating lipid organization, and its length and saturation influences the biological activity of the cationic lipids [84]. The nature of the linker group (for example ethers, esters, carbamates or amides) influences the conformational flexibility, degree of stability and biodegradability of the amphiphile. Although more efficient in the transfection process, usually ethers cause higher toxicity, since they form chemically more stable but non-biodegradable linkers when compared to esters. Esters links are biodegradable and less toxic but not so stable, which can thus affect the transfection outcome $[85,86]$.

Table 4. Advantages and disadvantages of viral and non-viral gene therapy vectors.

\begin{tabular}{|c|c|c|}
\hline \multirow{5}{*}{ Advantages } & \multirow{2}{*}{ High transduction efficiency } & Low immunogenicity and antigenicity \\
\hline & & Ease of production \\
\hline & Capacity to infect many types of cells & Low toxicity \\
\hline & Optimized endosomal escape & Drug/genetic material protection against degradation factors \\
\hline & Efficient delivery & Reduce tissue irritation \\
\hline \multirow{4}{*}{ Disadvantages } & Strong immune response & Low transfection efficiency \\
\hline & Difficult production & Lack of intrinsic tropism \\
\hline & Possibility of contamination with live virus & \multirow{2}{*}{ Lack of intrinsic mechanism for endosomal escape } \\
\hline & Limited plasmid size & \\
\hline
\end{tabular}


Not only monomeric cationic lipids but also dimeric amphiphiles with two hydrophobic tails and two polar headgroups linked by a covalently bonded spacer, known as Gemini amphiphiles, are explored for siRNA therapy applications, apart from anionic lipids (Table 5).

Neutral (helper) lipids like DOPE, cholesterol or monoolein are usually included in the formulations to help nucleic acids escape endosomes [87, 88], aid nucleic acids complexation by allowing a closer contact and packing of their helices [89], decrease toxicity associated with the cationic lipids [90, 91], or confer more favorable properties in terms of bilayers fluidity [92]. DOPE is one of the most widely used helper lipids, as it is believed to improve transfection efficiency due to its tendency to undergo a transition from a lamellar to a non-lamellar structure (hexagonal configuration), under acidic $\mathrm{pH}$, facilitating fusion with lipid bilayers and allowing lipoplex endosomal escape [87]. The presence of DOPE in the formulation can also decrease the charge ratio of lipid to DNA required to achieve maximum transfection in vitro, thus reducing the toxicity associated with an excess of lipid. Nevertheless, when in low serum levels or its absence, the aggregate instability imposed by helper lipid DOPE is advantageous in contact with serum proteins, as the dissociation of lipoplexes followed by aggre- gation often leads to precipitation and results in the loss of efficient transfection [93].

While many studies have demonstrated that lipoplex structure and function can be compromised in the presence of serum, little attention has been paid to the adsorption of specific proteins and how this might be affected by formulation parameters. After systemic administration, nanomaterials are exposed to various physiological fluids, mostly blood. The adsorption of proteins on NPs can modify the diverse physicochemical properties of NPs such as size, surface charge, surface composition, and functionality, hence giving NPs a new biological identity - protein corona (nanoparticle-protein complex) which is complex and unique to each nanomaterial and NP $[94,95]$. The advantages of including cholesterol in the formulations have been associated with a higher protection of nucleic acids from nuclease degradation [96], with effects on liposome bilayer fluidity [92], and with reduced binding of serum proteins to liposomes [97]. Also, Batker et al. characterized changes that occur in the protein corona when DOTAPbased lipoplexes are formulated with different amounts of cholesterol and have demonstrated that increased cholesterol contents mitigate the amount of protein that binds to lipoplexes, and the number of proteins that adsorb was also reduced in formulations containing $\geq 67 \mathrm{~mol} \%$ cholesterol [95].

Table 5. Example of liposomal systems used for siRNA delivery.

\begin{tabular}{|c|c|c|c|}
\hline Type of Liposomes & Lipid Composition & Purpose of Investigation & Ref \\
\hline \multirow{5}{*}{ Cationic } & DOTAP:DOPE & $\begin{array}{l}\text { Luciferase silencing on MCF-7 cells stably expressing the } \\
\text { luciferase protein }\end{array}$ & {$[110]$} \\
\hline & DOTAP:Chol & $\begin{array}{l}\text { Luciferase silencing on MCF-7 cells stably expressing the } \\
\text { luciferase protein }\end{array}$ & {$[110]$} \\
\hline & DODAB/C:MO & eGFP silencing on H1299 cells stably expressing the eGFP & {$[100]$} \\
\hline & DHDEAC:Chol:DSPE-PEG & $\begin{array}{c}\text { Tumor suppression and gene silencing in SK-OV-3 } \\
\text { xenograft mouse model }\end{array}$ & [111] \\
\hline & DOPE & Silencing gene expression in activated human macrophages & {$[112]$} \\
\hline \multirow[b]{2}{*}{ Gemini } & $\begin{array}{l}\text { 1,5-bis(1-imidazolilo-3-alkoxymethyl) pentane } \\
\text { dichloride dicationic gemini surfactants }\end{array}$ & $\begin{array}{l}\text { Complexation of different DNA and RNA sequences; cyto- } \\
\text { toxic evaluation }\end{array}$ & {$[113]$} \\
\hline & $\begin{array}{l}\text { bis-quat conventional and serine-derived Gem- } \\
\text { ini surfactants }\end{array}$ & $\begin{array}{l}\text { Delivery efficiency of anti-survivin siRNA; Effect of the } \\
\text { combination of chemotherapeutics with survivin gene si- } \\
\text { lencing }\end{array}$ & [114] \\
\hline Anionic & DOPG:DOPE $+\mathrm{Ca}^{2+}$ ions & $\begin{array}{l}\text { eGFP silencing on MDA-MB-231 cells stably expressing } \\
\text { the eGFP }\end{array}$ & {$[115]$} \\
\hline PEGylated & DODAB:MO:PEG-ceramide & BCR-ABL silencing on K562 cells & [116] \\
\hline Targeted & $\begin{array}{l}\text { Chol:DSPC:DODAP:PEG-ceramide:Trf- } \\
\text { coupled PEG-DSPE }\end{array}$ & BCR-ABL silencing on K562 cells & [13] \\
\hline Immunoliposomes & $\begin{array}{c}\text { DOTAP:Chol:DSPE-PEG-mal:anti-EGFR } \\
\text { antibody }\end{array}$ & $\begin{array}{l}\text { Luciferase silencing on SMMC-7721, LM3 and Hep3B cells } \\
\text { stably expressing the luciferase protein }\end{array}$ & [117] \\
\hline
\end{tabular}

Chol - cholesterol; DODAB - 1,2-dioleoyl-3-dimethylammonium-bromide; DODAC - 1,2-dioleoyl-3-dimethylammonium-chloride; DODAP - 1,2-dioleoyl-3-dimethylammoniumpropane; DOPE - 1,2-dioleoyl-sn-glycero-3-phosphoethanolamine; DOPG - 1,2-dioleoyl-sn-glycero-3-phospho-(1'-rac-glycerol); DOTAP - 1,2-dioleoyl-3-trimethylammoniumpropane; DSPC - 1,2-dioctadecanoyl-sn-glycero-3-phosphocholine; DSPE-PEG - 1,2-dioctadecanoyl-sn-glycero-3-phosphoethanolamine (polyethylene glycol); DSPE-PEG-Mal 1,2-distearoyl-sn-glycero-3-phosphoethanolamine-N-[maleimide(polyethylene glycol); eGFP - enhanced green fluorescence protein; EGFR - epidermal growth factor receptor; MO monoolein; PEG - poly(ethylene glycol); Trf- transferrin receptor. 
Monoolein has also been suggested as a helper lipid [98, 99] not only due to its ability to fluidize and stabilize liposomal structures, but also due to its ability to form nonlamellar inverted cubic phases, known to be intermediates of fusion processes $[98,100,101]$, discussed in more detail in section 6 .

\subsection{Mechanism of siRNA-lipoplexes Formation}

Since both siRNA and DNA are double-stranded nucleic acids with anionic phosphodiester backbones, they interact electrostatically with cationic lipids and spontaneously form supramolecular assemblies - the so-called lipoplexes. The type of lipid, lipid composition (cationic lipid:neutral lipid molar fraction), and ratio between the positive charges of cationic lipids and the negative charges of nucleic acids (charge ratio, C.R.) determine lipoplex morphology. Lipoplexes composed of ODNs and siRNA show morphologies similar to that of DNA lipoplexes [102], with nucleic acids observed between lipid layers, forming multilayered structures. Nevertheless, the different size and structure of pDNA and ODNs/siRNA makes the lipoplex formation process slightly different for the two types of molecules. Weisman et al. [103] proposed a model where negatively charged singlestranded ODN molecules act as bridges between cationic membranes, stabilizing the condensed lamellar phases. The ODN-mediated adsorption of lamellae, one by one, is followed by the restructuration of the lipids, explaining the presence of lamellar defects. Although very similar to the mechanism of liposome reorganization proposed for DNAlipoplexes [104], this model does not suggest the existence of lipid mixing. Other studies have nevertheless reported fusion among vesicles during ODN-lipoplex formation [105].

Additional differences between ODN and DNAlipoplexes include a smaller aqueous thickness associated with ODN than with DNA or less organization of ODNs between the lipid layers when compared to DNA [103]. Another aspect to consider is that pDNA has several kilo base pairs (bp), while siRNA usually has 21 to $23 \mathrm{bp}$, affecting the electrostatic interactions with cationic liposomes. Moreover, the hydroxyl group in the 2'- position of the ribose makes RNA much less stable that the deoxyribose of DNA.

The different sizes of siRNA and pDNA also influence the number of positive charges needed to achieve the same complexation efficiency. When using the same polycation, the fact that pDNA has a higher molecular weight and higher negative charge than siRNA can result in the formation of more stable complexes for pDNA than siRNA. Therefore, unpacking of pDNA could be more difficult than the release of siRNAs from the complex [106].

\section{STRATEGIES TO OVERCOME THE BARRIERS FOR EFFICIENT SIRNA DELIVERY IN A THERA- PEUTIC STRATEGY}

siRNAs can only exert their silencing effect once they are incorporated into the RISC complex in the cytosol of the cells. Nevertheless, before siRNAs reach their site of action, numerous barriers must be overcome that depend not only on the targeted organs but also on the siRNA administration route used. Although local delivery of siRNA poses less challenges when compared to systemic administration, in many cases systemic delivery is the only way to reach certain disease sites.

The general steps that siRNA has to overcome, from the site of administration to the site of action, include: distribution through the organs blood circulation; transport from the blood vessels within the organ to the interstitium; transport across the interstitial space to the target cells; and internalization by the target cells. Endocytosis is the major route of siRNA internalization and siRNA endosomal entrapment and lysosomal degradation are additional barriers for its therapeutic use. Moreover, even when siRNA escapes from endosomes, the viscosity of the cytoplasm and the presence of organelles are still obstacles to its loading into the RISC complex.

(Fig. 2) represents some of the main barriers faced by nanocarriers after systemic administration: (I) aggregation and interaction with blood components; (II) internalization of the nanocarriers by the targeted cells; (III) nucleic acids escape from endosomes.

\subsection{PEGylation to Improve Nanocarrier Stability in Physiological Conditions}

Initial strategies to improve liposome circulation time were based on mimicking erythrocyte membranes, by performing modifications with gangliosides like monosialoganglioside (GM1) [107]. Later, hydrophilic polymers like poly(ethylene glycol) (PEG) were introduced with the same purpose [108, 109].

Nowadays nanocarriers are usually coated with hydrophilic materials in order to form a protective hydrophilic layer around them. The polymers' flexible chains occupy the space near the liposomal surface, preventing other macromolecules from being in the same space, decreasing the binding of opsonins and thus uptake by macrophages.

As a result, these long-circulating liposomes can take advantage of the enhanced permeability and retention effect (EPR), accumulate in the interstitial space of solid tumors [118], which is a useful approach when the target tissue is a tumor.

Although different long hydrophilic polymer chains and non-ionic surfactants were developed and used as shielding groups, such as polysaccharides, polyacrylamide, poly(vinyl alcohol), poly (N-vinyl-2-pyrrolidone), PEG and PEGcontaining copolymers, PEG is still the most widely used material to achieve steric stabilization [119]. PEG is a linear polyether diol with several properties that make it attractive for biomedical applications [120], such as good biocompatibility, very low toxicity, immunogenicity and antigenicity, good excretion kinetics and solubility in both aqueous and organic media. Moreover, PEG is highly hydrated in water, forming a large excluded volume where the hydrophilic chains are in rapid motion [121].

A common method to graft PEG onto the surface of liposomes (a process called PEGylation) is to use crosslinked lipids to anchor the polymer to the liposomal membrane [120]. PEG linked to distearoylphosphatidylethanola- 


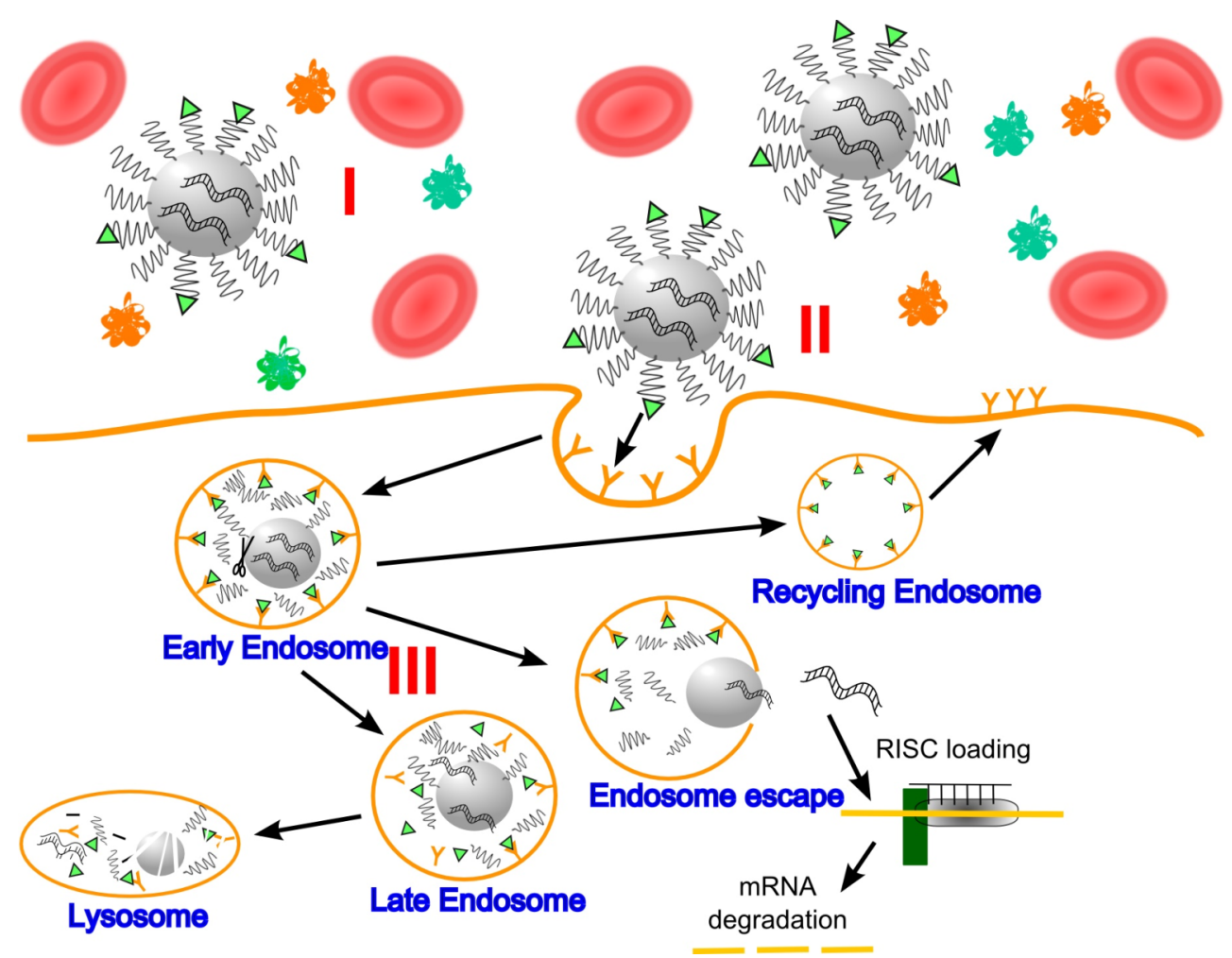

Fig. (2). Common strategies to overcome the barriers to systemic, non-viral delivery of siRNA. I. PEGylation of nanocarriers to avoid aggregation and unspecific interactions with blood components, e.g. cells and proteins. II. Attachment of targeting ligands to improve nanocarriers' cellular uptake by receptor-mediated endocytosis. III. Use of "intelligent" materials to allow dissociation of PEG chains from the surface of nanocarriers to promote endosomal escape. The components in the figure are not represented at scale.

mine (DSPE) (DSPE-PEG), is a well-known example [108]. Physical adsorption of PEG, or covalently attachment of reactive groups onto the surface of liposomes, can also be used [120]. Depending on graft density, PEG can assume different conformations at the surface of liposomes (mushroom or brush). Although some opsonization is always inevitable, it can be minimized by the presence of a near perfect PEG shell surrounding the liposomes. However, excessive percentages can lead to the formation of micelles composed of PEG-lipids that may act as liposome destabilizing agents [122]. Dar et al. investigated different strategies for preparing liposomes with three different PEG amounts $(2.5 \mathrm{~mol} \%$, $5 \mathrm{~mol} \%$ and $8 \mathrm{~mol} \%$ ) to identify the best possible formulation that leads to efficient in vivo gene silencing. Intravenous administration of SEV-5 (Vesicles containing $5 \mathrm{~mol} \%$ of DSPE-PEG-2000) at $5 \mathrm{~mol} \%$ PEG in ovarian cancer xenograft mouse model confirmed the stability and nontoxic nature of the formulation and the delivery of therapeutic siRNA mediated by these system led to significant tumor tropism and efficient gene silencing [111]. Therefore, good stealth liposomes include a high - but not excessive- density of PEG-lipids at their surface.

PEGylation of liposomes not only extends circulation times in blood but it also improves stability by avoiding aggregation. Braeckmans et al. [123] used fluorescent Single Particle Tracking (fSPT) to analyze if PEGylation actually suppressed aggregation of liposomes in blood. The authors found that the presence of $10 \%$ DSPE-PEG significantly reduced liposomes aggregation when compared to the nonPEGylated liposomes. Dakwar and coworkers studied the colloidal stability of liposomes in mouse intraperitonial fluid, plasma from a healthy patient and ascites fluid from a patient diagnosed with peritoneal carcinomatosis [124]. The authors found that the inclusion of PEG improved liposome stability in the different fluids.

However, PEG's presence can be a disadvantage for some phases of the delivery process: PEGylated nanocarriers might not adequately encapsulate and protect nucleic acids from nuclease activity, and PEG can inhibit nanocarriers cellular internalization or difficult siRNA endosomal release $[125,126]$. These evidence clearly suggest a "PEGylation dilemma", since there is a need for a stable PEG coating when nanocarriers are in blood circulation, to avoid recognition by the immune system and prevent aggregation, but simultaneously PEG chains can become an obstacle for cellular internalization and endosomal escape. The presence of PEG chains on the liposome surface can avoid the release of genetic material from endosomes by more than one mechanism: (i) stabilization of the lipoplexes lamellar organization, impairing the structural reorganization required for endosomal membrane destabilization [126]; (ii) inhibition of the contact between lipids from liposomes and from endosomal membranes, that is essential for membrane destabilization and nucleic acids release [127]. Therefore, there is the need for so-called smart materials, able to respond at the appropriate time and place and provide PEG chains association/dissociation accordingly.

Different environment-responsive PEG-derivatives have been developed to overcome the "PEGylation dilemma": $\mathrm{pH}-$ 
sensitive linkers between PEG and the lipid anchors, that are stable at neutral $\mathrm{pH}$ but hydrolyzed in acidic environment [119]; removal of PEG triggered by the action of enzymes [128]; use of conjugates of lipids and hydrophilic polymers as exchangeable moieties, which can dissociate from the liposomes with different kinetics. PEG-ceramides (PEG-Cer) form one such example of semi-stable coatings, able to offer good protection and provide stability in blood while maintaining good cellular uptake and transfection activity [129]. Other PEG-lipid conjugates include PEG-phosphatidylethanolamine (PEG-PE), PEG-diacylglycerol, PEG-dialkyloxypropylamine or PEG-( $N$-methyl-4-alkylpyridinium chlorides) (PEG-SAINT) conjugates [119]. The structure, length and saturation of the PEG-lipid conjugates define the anchorage strength of PEG to the lipid bilayer and the kinetics of diffusion [119]. Usually, shorter acyl chain groups (for instance 1,2-Dimyristoyl-sn-glycero-3-phosphoethanolamine (DMPE) (C14) > (1,2-Dipalmitoyl-sn-glycero-3-phosphoethanolamine) DPPE (C16) > DSPE (C18)) and unsaturated anchors diffuse faster than longer, and saturated, acyl chain groups. This usually results in improved transfection efficiencies in vitro, but reduced circulation times in vivo. Thus, a compromise between prolonged circulation times, protection of nanocarriers, interaction with target cells and delivery of the payload must be reached to design efficient nanosystems.

An additional important factor to consider when designing a nanocarrier system is the preparation method. The simplest way to form PEGylated siRNA lipoplexes is by directly mixing the nucleic acids with the PEGylated liposomes. However, for high PEG densities, siRNA becomes bound to the outer surface of the liposomes, making them susceptible to premature release into the blood stream [125]. An alternative method is to form the siRNA-lipoplexes with nonPEGylated cationic liposomes and then proceed to the PEG grafting of the formed lipoplexes - the post-PEGylation alternative [116]. This allows a better protection of the siRNA inside the lipid bilayers while taking advantage of the PEG shielding effect necessary for systemic administration. Other methods consist in hydrating a lipid film which already includes PEG, with a siRNA aqueous solution, or using the ethanolic dilution method for the preparation of siRNAlipoplexes [130].

\subsection{Targeted Delivery to Improve the Effectiveness}

It is thought that the predominant route for nanocarrier internalization is endocytosis, triggered by non-specific electrostatic interactions between the positive nanocarriers and negative proteoglycans at the surface of the cells [131]. Nevertheless, nanocarriers can also be tailored for receptormediated endocytosis (Table 6). In fact, by using targeted delivery, the intracellular drug concentration can be increased, more effective tumor targeting can be achieved, non-specific toxicity can be reduced and the overall therapeutic effect can be enhanced [132].

Several studies indicate that nanocarriers enter cells via clathrin-dependent endocytosis (or clathrin-mediated endocytosis (CME)), caveolae-mediated endocytosis and/or macropinocytosis and that these pathways of entry are not mutually exclusive. More importantly, not all internalization pathways result in an effective release of the nanocarriers' payload into the cytoplasm. When receptor-mediated endocytosis is not used, internalization of nanocarriers depends on their size, surface charge and shape, as well as on the cell type [133-135].

\subsection{Stimuli-sensitive Molecules to Improve Endosomal Escape}

Escape of nucleic acids from endosomes implies that nanocarriers are able to induce a perturbation on the lamellar structure of endosome membranes. The mechanism by which cationic liposomes escape from endosomes can be either by induction of a fusion event between lipoplex and endosome membranes or by a local and transient membrane perturbation that leads to the formation of pore-like structures. These mechanisms can be explained by the displacement of anionic lipids from the cytoplasm-facing monolayer into the interior of the endosome, by a flip-flop mechanism. During the process, anionic lipids of the endosomal membrane laterally diffuse into the lipoplexes, resulting in the formation of an "ion pair" between anionic phospholipid headgroups and cationic lipids, charge neutralization, and reduction in the headgroup area that will favor the inverted conformation according to geometrical restrictions [136]. At the same time, the cationic charge neutralization results in the dissociation of the nucleic acid from the lipoplex and escape into the cytosol [137]. For instance, replacement of DOPE by 1,2-Dioleoyl-sn-glycero3-phosphocholine (DOPC), a structural analog of DOPE with no activity to form inverted hexagonal phases under acidic $\mathrm{pH}$, resulted in no helper activity and no transfection efficiency [138]. The fact that DOPC is more strongly hydrated than DOPE can decrease the proximity of interaction nanocarrier-intracellular membranes and affect escape from endosomes [131]. Lipoplexes can adopt a large variety of non-lamellar phases, like micellar and cubic phases, all able to perturb the bilayer structure of endosomes [131].

Apart from the inclusion of helper lipids in the liposomal formulations, other approaches have been investigated to potentiate the release of nucleic acid from lipoplexes into the cytosol of the target cells. For example, pH-responsive liposomes containing synthetic glutamic acid-based zwitterionic lipids showed improved fusogenic potential at acidic $\mathrm{pH}$ [139]. Cationic liposomes can also be modified in order to perform a proton sponge effect similar to polyethylenimine (PEI). Kumar et al. [140] reported the synthesis and transfection efficiency of novel histidylated cationic amphiphiles containing a single endosome-disrupting histidine head group, which facilitated the release of DNA into the cytoplasm of the cells. Other alternative can be the use of cellpenetration peptides (CPPs), cationic and/or amphipathic 1030 amino acid sequences able to cross the plasma membrane or enter cells via endocytosis and induce endosomolytic activity. CPPs can form complexes with nucleic acids, through electrostatic interaction, or can be incorporated into more complex delivery systems like liposomes of polymer nanocarriers. The development of these peptides was inspired by the endosomal disruptive properties of fusogenic sequences of viral fusion proteins. It is well-known that endosomal escape of the influenza virus is driven by the presence of hemagglutinin subunit HA2, a fusogenic peptide with a short chain of N-terminal amphiphilic anionic peptides [141]. 
Table 6. Examples of targeting molecules explored to achieve specific nucleic acids/drug delivery.

\begin{tabular}{|c|c|c|c|c|c|}
\hline & Target/targeting Molecule & Endocytosis Pathway & Overexpression & Example & Ref. \\
\hline \multirow{2}{*}{ Proteins } & $\begin{array}{c}\text { Transferrin receptor }(\mathrm{TfR}) \\
\text { transferrin }(\mathrm{Tf})\end{array}$ & CME & $\begin{array}{l}\text { TfR overexpressed in malig- } \\
\text { nant cells }\end{array}$ & $\begin{array}{c}\text { Tf-liposomes to silence } \\
\text { BCR-ABL in leukemic cells }\end{array}$ & {$[13]$} \\
\hline & $\begin{array}{l}\text { Integrin } \alpha_{v} \beta_{3} ; \text { arginine-glycine- } \\
\text { aspartic acid (RGD) peptide }\end{array}$ & Caveolae & $\begin{array}{c}\alpha_{\sqrt{v}} \beta_{3} \text { overexpressed in angio- } \\
\text { genic endothelium }\end{array}$ & $\begin{array}{l}\text { RGD-liposomes loaded } \\
\text { with doxorubicin }\end{array}$ & [142] \\
\hline Antibodies & $\begin{array}{l}\text { Tyrosine kinase MET; scFv } \\
\text { antibody binding MET }\end{array}$ & $\mathrm{CME}$ & $\begin{array}{l}\text { MET involved in growth, } \\
\text { invasion and metastasis in } \\
\text { cancer }\end{array}$ & $\begin{array}{l}\text { scFv-PEG-liposomes loaded } \\
\text { with doxorubicin }\end{array}$ & [143] \\
\hline Small molecules & Folate receptor (FR); folate (fol) & $\begin{array}{l}\text { Caveolae and clathrin- } \\
\text { independent endocyto- } \\
\text { sis; CME }\end{array}$ & $\begin{array}{l}\text { FR- } \alpha \text { : malignant tissues of } \\
\text { epithelial origin. FR- } \beta \text { : pa- } \\
\text { tients with CML and AML }\end{array}$ & $\begin{array}{l}\text { fol-nanocarriers to silence } \\
\text { Her-2 in human KB cells. }\end{array}$ & [144] \\
\hline Aptamers & $\begin{array}{c}\text { Nucleolin; AS1411 (specifically } \\
\text { binds to nucleolin) }\end{array}$ & $\begin{array}{l}\text { dynamin-independent; } \\
\text { more than one pathway }\end{array}$ & $\begin{array}{l}\text { Nucleolin overexpressed on } \\
\text { the surface of cancer cells }\end{array}$ & $\begin{array}{l}\text { AS1411-PEG-liposomes to } \\
\text { silence BRAF in melanoma }\end{array}$ & {$[145]$} \\
\hline
\end{tabular}

$\mathrm{CME}$ - clathrin-mediated endocytosis; $\mathrm{scFv}$ - human single chain variable fragment.

The N-terminus peptide undergoes a conformational change induced by $\mathrm{pH}$ alterations, which trigger fusion of the viral membrane with endosomal membranes, leading to viral genome leakage to cytosol. GALA (glutamic acid-alanineleucine-alanine) is an example of a synthetic amphipathic $\mathrm{pH}$-sensitive endosome-disruptive peptide. A drop in $\mathrm{pH}$ promotes a conformational change from a random coil to an amphipathic $\alpha$-helix, leading to disruption of lipid membranes and release of their content. The incorporation of GALA with transferrin-containing lipoplexes significantly increased luciferase gene expression in COS-7 cells [146].

\subsection{Chemical Modifications of Nucleic Acids}

The direct use of naked siRNA is limited to local delivery and to specific sites such as the eye, nose and lungs and systemic application of siRNA therapeutics requires the use of safe and efficient delivery systems, including direct chemical modification of siRNA and/or optimization of delivery systems (ex: liposomal formulations, nanoparticle conjugation and antibodies that target cellular moieties) [147].

Both DNA and RNA oligonucleotides can be modified chemically to alter several features which are important for successful delivery to cells (examples in Table 7). RNA is much more susceptible to nuclease activity, therefore, its modifications are particularly relevant. Chemical modifications of the RNA backbone have been developed in order to increase resistance to nucleases, biodistribution, thermal stability improvement, specificity for target mRNA and blood lifetime extension without altering the nucleic acid sequence or interfering with silencing efficiency.

Transfection efficiency of mRNA has been greatly improved and the half-life of mRNA has been intensely increased, ranging from a few minutes to several hours by chemical modifications. The advantage of using drugs with short half-lives is that they can be rapidly removed from the patient should adverse reactions develop. However, the therapy must usually be administered either at relatively high concentration and/or frequency to maintain an effective dose. In this regard, it is important to guarantee that repeated administrations are safe and feasible [148]. Specific sequence motifs can be recognized by Toll-like receptors (TLRs) and induce cellular immune responses, which constitutes another challenge [149]. Base modifications can reduce immune activation, and the addition of modified nucleotides into siRNA suppresses unwanted immunostimulation [150]. Nevertheless, recent studies reported that, in certain circumstances, immune stimulation could be beneficial and may represent an alternative treatment strategy against cancers and viral infections [151].

Common modifications to the ribose ring include fluorine (2'-F), methoxy (2'-OMe), locked nucleic acids (LNA) and unlocked nucleic acids (UNA). Phosphorothioate, boranophosphate modifications, uncharged nucleic acid mimics or linkage of hydrophobic ligands (e.g., cholesterol) are other examples [49, 152-154]. In fact, some of the ongoing clinical trials use naked siRNA, although chemically modified siRNAs, which are delivered locally, reduce the risk of RNA degradation and systemic immune activation associated with systemic delivery. Alnylam Pharmaceuticals has several siRNA drugs undergoing clinical trials. Their most advanced drug, also one of the most advanced siRNA therapeutics, Patisiran, is a Lipid Nanoparticle (LNP) containing siRNA against mutant transthyretin for the treatment of transthyretin amyloidosis [155].

Phase I and II studies of siRNA therapeutics in the past 2 years have demonstrated potent (as high as $98 \%$ ) and durable, for weeks, gene knockdown in the liver, with some signs of clinical improvement and without unacceptable toxicity [153] and, recently, announced positive Phase III data on their therapy for hereditary ATTR amyloidosis. (ClinicalTrials.gov. NCT01960348: APOLLO - The study of an investigational drug, patisiran (ALN-TTR02), for the treatment of transthyretin (TTR) - mediated amyloidosis https://clinical trials.gov/ct2/show/NCT01960348 Accessed 12 October 2017). Other companies have also invested in the application 
Table 7. Examples of chemically modified antisense oligonucleotides.

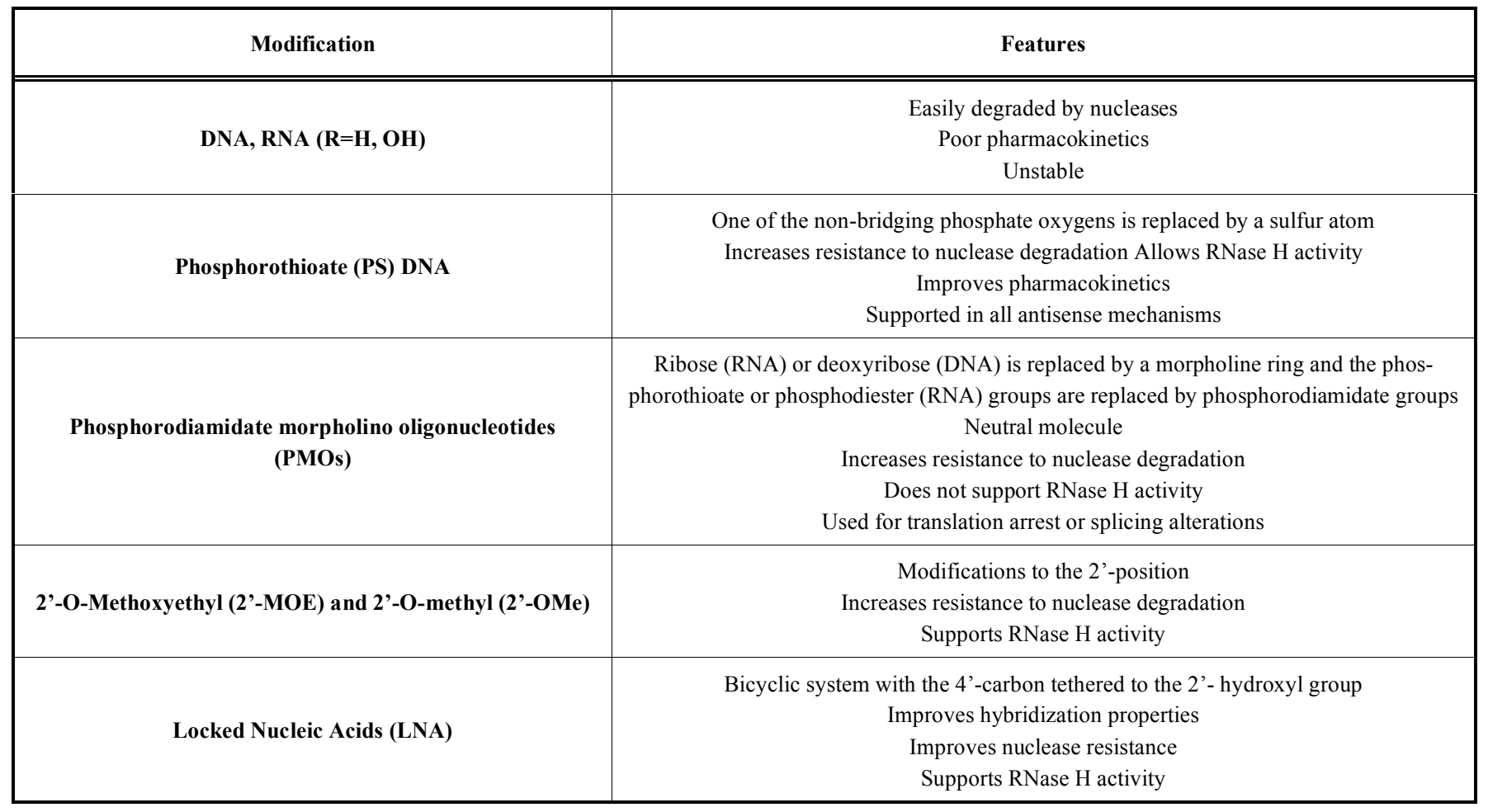

of lipoplex-based siRNA drugs due to their advantages in the genetic therapy field [156].

\section{LESSONS LEARNED FROM THE DODAB/C:MO LIPOSOMAL SYSTEM}

Over the past years, siRNA nanocarriers of increased complexity have been developed, incorporating a variety of molecules to improve stability, provide fusogenicity and allow active targeting by the system. However, the basic understanding of the characteristics driven by the physicochemical properties of the nanosystem is sometimes overlooked, delaying the progression into the clinical setting. In this section, we demonstrate how important the full characterization of a liposomal system can be for the understanding of its biological performance and to provide information for a successful, rational design of a siRNA nanocarrier.

Our research group has been working with a formulation composed by the cationic lipids dioctadecyldimethylammonium bromide/chloride (DODAB/C) and the neutral lipid monoolein (MO) in the past years for nucleic acids/drug delivery [98-100, 116, 157-164]. DODAB and DODAC are composed by a hydrophobic group formed by two 18 carbon long acyl chains (C18:0), linked to a stable quaternary ammonium headgroup. The positively charged monovalent counter-ions bromide $\left(\mathrm{Br}^{-}\right)$or chloride $\left(\mathrm{Cl}^{-}\right)$form DODAB and DODAC lipids, respectively (Fig. 3).

$\mathrm{DODAB} / \mathrm{C}$ vesicles can be prepared by sonication or extrusion [165], ethanol injection [159], or by simply dissolving the lipid powder in water, above the lipids' transition temperature $\left(\mathrm{T}_{\mathrm{m}}\right)$ [166]. DODAB and DODAC CVC are very low, allowing the formation of bilayer structures at con- centrations as low as $10 \mu \mathrm{M}$ [167]. Their phase behavior has been extensively studied, and the lipids found to form bilayer structures when dispersed in aqueous media and above $\mathrm{T}_{\mathrm{m}}$, although with different the thermotropic behavior for DODAC and DODAB [168]. The hydrated $\mathrm{Cl}^{-}$is larger than the hydrated $\mathrm{Br}$ [169], implying that $\mathrm{Cl}^{-}$ion cannot be as proximal to the cationic headgroup as $\mathrm{Br}^{-}$, being less competent in the neutralization of its positive charges. Thus, DODAC has a less ordered polar region due to stronger repulsive interactions between the lipid headgroups. Although DODAB forms bilayers more densely packed at the headgroup region than DODAC [167, 169], it exhibits lower $\mathrm{T}_{\mathrm{m}}$ values and forms bigger vesicles than DODAC.

1-Monoolein (1-(cis-9-octadecenoyl)-rac-glycerol, MO) is a neutral lipid composed by an unsaturated hydrocarbon chain attached to a glycerol backbone by an ester bond (Fig. 3). MO is biodegradable since it can be degraded by esterase activity in different tissues $\frac{172}{}$. Its biocompatibility and nontoxicity made MO extensively used in different areas, ranging from pharmaceuticals, food, cosmetics, and agriculture, to protein crystallization $[171,172]$. The monoolein/water phase diagram (Fig. 3) shows that MO can form several different phases according to temperature and water content, including lamellar $\left(\mathrm{L}_{\alpha}\right)$, inverted hexagonal $\left(\mathrm{H}_{\mathrm{II}}\right)$, and bicontinuous cubic phases (type $\mathrm{G}$ (gyroid, $\mathrm{Q}_{\text {II }}^{\mathrm{G}}$ ) and cubic phase $\mathrm{D}$ (diamond, $\mathrm{Q}_{\mathrm{II}}{ }^{\mathrm{D}}$ ) [173]. An unusual feature of the water/monoolein system is the excess-water phase separation region. MO has the particularity of forming two inverted bicontinuous cubic phases in excess water, consisting of two intertwined but not interpenetrating water channels separated by a lipid bilayer surface $[171,173]$. MO cubic phases can contain up to $40 \%(\mathrm{w} / \mathrm{w})$ of water. 
A
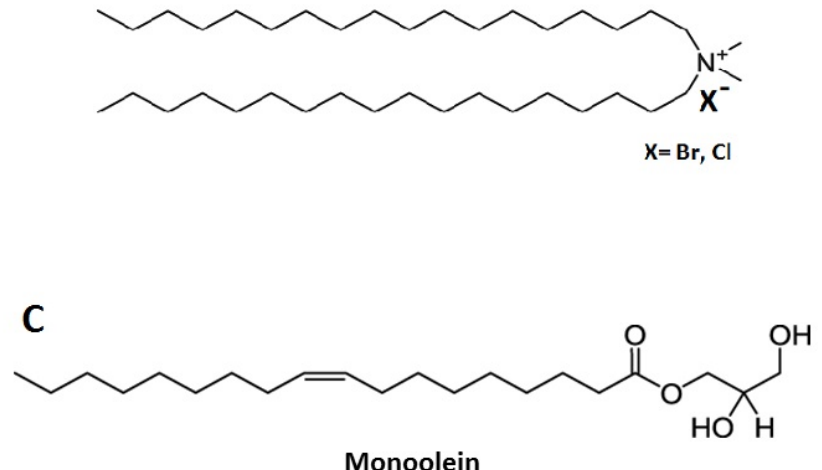
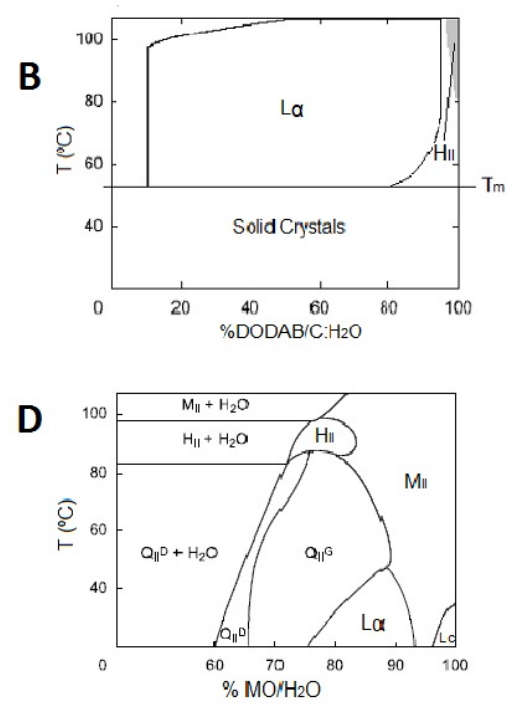

Fig. (3). Representation of the chemical structure of dioctadecyldimethylammonium lipids (A) and phase diagram of DODAB (adapted from [170]) (B), chemical structure of monoolein $(\mathrm{MO})(\mathbf{C})$ and phase diagram of $\mathrm{MO}$ (D) 157.171. When $\mathrm{X}=\mathrm{Br}$ dioctadecyldimethylammonium bromide (DODAB) is formed, while for $\mathrm{X}=\mathrm{Cl}$, dioctadecyldimethylammonium chloride (DODAC) is formed.

The presence of lipid and aqueous domains in MO cubic phases allows the solubilization of both hydrophilic, lipophilic and amphiphilic compounds, which makes this molecule very interesting for drug delivery purposes. Not only can it accommodate high payloads, but it also allows the combination of molecules with different hydrophilicity like nucleic acids and drugs in one single nanocarrier. Moreover, MO can help to overcome one of the most important bottlenecks in nucleic acids delivery - endosomal escape - due to its fusogenicity.

The combination of two lipids that form such different lyotropic phases provides a rich panel of structural organizations that can be tailored according to specific applications. A detailed physicochemical characterization of the DODAB:MO system revealed that two different aggregation structures could be obtained, depending on the cationic:neutral lipid molar fraction [159] (Fig. 4).

When DODAB is in excess $(\chi D D D A B \geq 0.5)$, bilayerbased structures are predominantly observed, with size and fluidity dependent on the exact molar fraction and temperature. When $\chi \mathrm{DODAB}<0.5$, densely packed cubic-oriented particles are mainly observed. The same dual behavior was seen for pDNA lipoplexes $[98,99]$ : for $\chi \mathrm{DODAB} \geq 0.5$, multilamellar structures of lipid bilayers alternating with DNA monolayers were formed; for $\chi \mathrm{DODAB}<0.5$, there is the formation of high-curvature zones, where lipid bilayers cross each other with DNA monolayers stacked between them. These are presumed to be MO-rich domains alternating with DODAB-rich domains (with multilamellar organization), supporting the existence of inverted structures in the liposomal system.

The formulation DODAB:MO was first proposed as a non-viral gene delivery system in 2010 by Real Oliveira et al. [174], and more recently DODAB:MO and DODAC:MO liposomes were also validated for siRNA delivery [100, 116, 164] MO-based formulations form small sized siRNAlipoplexes with positive surface charge, were highly internal- ized by the cells and able to silence expression of the model protein eGFP [100]. Nevertheless, the different DODAX:MO membrane properties strongly influenced liposomes' bio-interface, defining stability and interaction with cellular models (Fig. 4).

DODAB:MO and DODAC:MO liposomes present different lipid organization driven by the presence of different counter-ions on the cationic lipids: bromide and chloride define the mode $\mathrm{MO}$ is integrated into DODAB and DODAC systems [100]. For formulations prepared at cationic:neutral lipid molar fraction (2:1), a homogeneous integration of $\mathrm{MO}$ into DODAC bilayers is observed, inducing higher disorder to this system comparing to what is observed for the DODAB system. The higher membrane packing determined for DODAB:MO (2:1) formulation is explained by the formation of DODAB-rich and MO-rich domains, which results in a lower disturbing effect of MO when compared to when it is homogeneously integrated throughout the membrane [100]. The effects of $\mathrm{MO}$ on the transition temperature and enthalpy of $\mathrm{DODAB} / \mathrm{C}: \mathrm{MO}$ liposomes also pointed to a more homogeneous incorporation into DODAC- than into DODABbilayers [100]. MO's more uniform distribution in DODAC:MO bilayers resulted in a slightly greater ability to fuse with model endosomal membranes when compared to DODAB:MO bilayers [100]. Nevertheless, this aspect also compromised stability and DODAC:MO (2:1) liposomes released almost all of their siRNA content after $1 \mathrm{~h}$ incubation in physiological conditions. This strongly reduced DODAC:MO lipoplexes efficiency, leading to lower cellular internalization and ability to silence the eGFP protein when compared to DODAB:MO liposomes (Fig. 4).

For formulations prepared at cationic:neutral lipid molar fraction of (1:2), the counter-ions' effects on membrane organization are not so discernible, and DODAB:MO (1:2) and DODAC:MO (1:2) systems seem more alike, resulting in similar biological responses (Fig. 4). The incorporation of a higher amount of MO into the bilayers disrupts DODAB-rich 


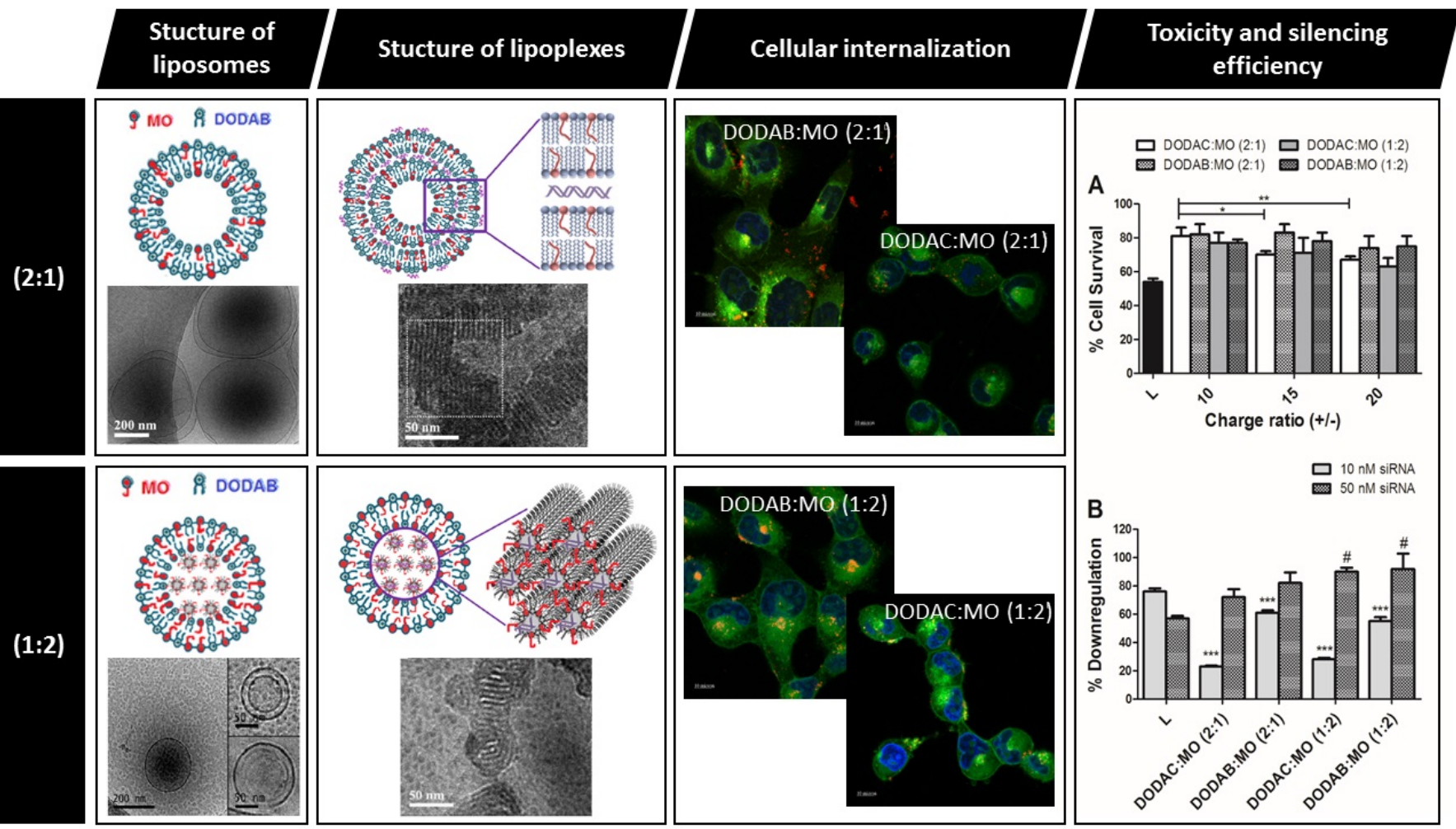

Fig. (4). Representation of the DODAX:MO liposomes and lipoplexes structures, lipoplexes cellular internalization, cytotoxicity and silencing efficiency, according to the cationic:neutral lipid molar fraction. In DODAX:MO (2:1) the lamellar phase is predominant and MO is within the DODAB lamellar phase. In DODAX:MO (1:2), MO is organized in inverted non-lamellar structures limited by DODAX lamellar phases. Adapted from $[100,158,159,162]$.

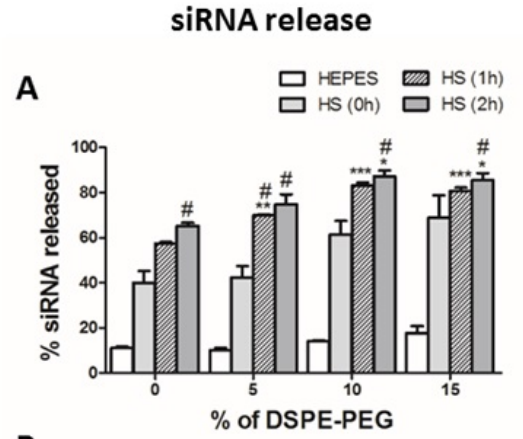

B

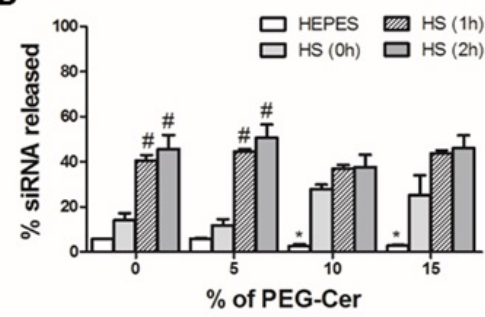

siRNA-lipoplexes aggregation

C

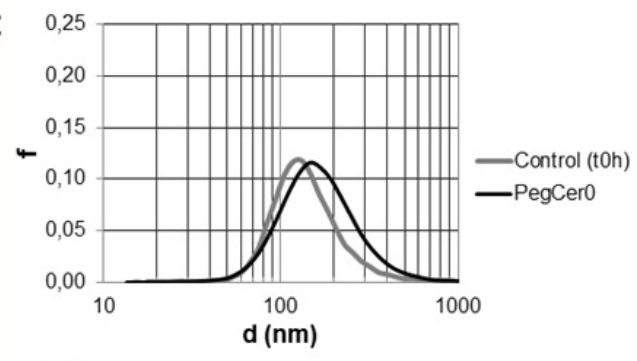

D

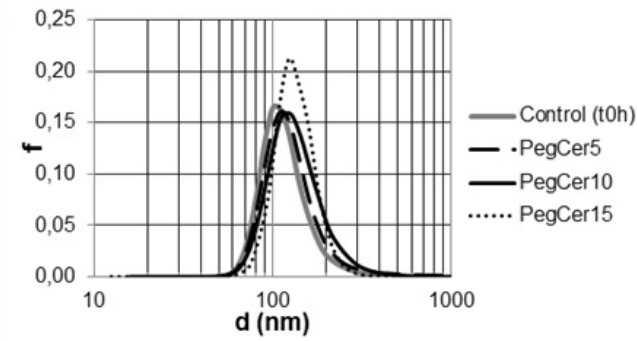

Silencing efficiency

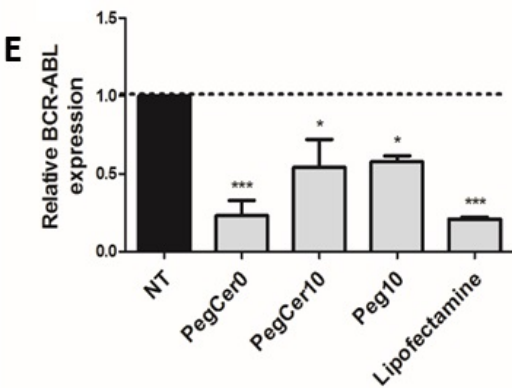

F

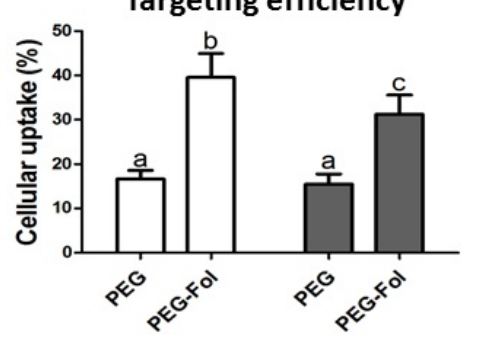

Fig. (5). Representative results obtained during the optimization of the DODAX:MO lipoplexes PEGylation for systemic siRNA administration. Results show the lipoplexes ability to retain siRNA after incubation in human serum (A and $\mathbf{B})$, their ability to avoid aggregation $(\mathbf{C}$ and D), their capacity to downregulate BCR-ABL fusion gene (E), and finally cellular internalization after incorporation of folate as a targeting molecule (F). Adapted from 116.164.

domains. In fact, after a certain percentage, MO is probably excluded from the bilayer membranes, forming MO-rich inverted non-lamellar structures in the core of the liposomes (Fig. 4). 
DODAB:MO (2:1) was further optimized for systemic siRNA delivery (Fig. 5). Different pegylation strategies were tested (pre-pegylation with DSPE-PEG and post-pegylation with PEG-ceramide), and the best system was validated in a leukemia cell line (K562 cell line) that expresses the pathogenic BCR-ABL fusion protein [116].

Both the PEGylation method and type of PEG moiety (DSPE-PEG or PEG-ceramide) influenced lipoplexes performance in physiological conditions [116]. Pre-PEGylation of DODAB:MO (2:1) siRNA-lipoplexes resulted in lower cellular internalization and silencing efficiency. The presence of DSPE-PEG decreased cellular internalization, probably affecting endosomal escape, which compromised siRNAlipoplexes silencing efficiency outcome. The looser postPEGylation with PEG-ceramide was beneficial in these aspects (siRNA protection, siRNA-lipoplexes internalization and silencing efficiency), but it still provided enough stability to avoid massive aggregation in human serum and decrease binding of serum proteins. PEG-ceramide nanocarriers better-retained siRNA in human serum (Fig. 5A and 5B), avoiding massive aggregation (Fig. 5C and 5D), and effectively silencing the BCR-ABL gene (Fig. 5E), to an extent sufficient to affect K562 cell survival [116].

In a different work, a targeting approach was also followed to improve delivery efficiency (Fig. 5F). Functionalized DODAC:MO:PEG-folate were prepared and found to be better internalized by FR- $\alpha$ positive breast cancer cells when compared with FR- $\alpha$ negative cells and to systems lacking PEG-folate [164].

These works show the potential of MO-based liposomes for siRNA delivery and reinforce the importance of a careful optimization and selection of lipid components before in vivo application. Nevertheless, a good clinical response is expected for DODAB:MO (2:1) siRNA-lipoplexes, since DODAB:MO liposomes were already demonstrated to be well tolerated by mice [160] in terms of toxicity and recognition by the immune system.

\section{CONCLUSION}

The fact that liposomes have been used in the clinic for more than 20 years, especially for chemotherapy, together with the simplicity by which they form complexes with negatively charged nucleic acid molecules, makes lipidbased nanosystems as one of the most attractive siRNA delivery vehicles for gene therapy. Nevertheless, there are still important obstacles to overcome before RNAi constitutes an effective therapeutic approach, particularly related to the nucleic acids delivery process. Several strategies can be used to improve delivery efficiency, namely concerning nanocarrier stability in biological fluids, their ability to actively target specific cells, as well as to take advantage of different physiological stimuli to carry siRNA into the cytoplasm of the cells. This review covers some of these strategies, explaining the mechanisms behind each approach and giving examples of liposomal-based systems optimized to overcome specific barriers to the delivery process. An efficient delivery of siRNA to target cells will allow the use of lower doses and decrease off-target effects associated with RNAi therapeutic approaches. Understanding the relationship between physicochemical properties and biological effects is the first step in the development of a successful nanocarrier, as exemplified by the lessons learned from the liposomal system $\mathrm{DODAB} / \mathrm{C}: \mathrm{MO}$.

\section{CONSENT FOR PUBLICATION}

Not applicable.

\section{CONFLICT OF INTEREST}

The authors declare no conflict of interest, financial or otherwise.

\section{ACKNOWLEDGEMENTS}

This work was further supported by FEDER through POFC-COMPETE and by national funds from Fundação para a Ciência e a Tecnologia (FCT), through the projects PEst-OE/BIA/UI4050/2014 (CBMA) and PEst-C/FIS/ UI0607/2013 (CFUM). Ana Oliveira was the recipient of a FCT scholarship (SFRH/BD/68588/2010). The authors would also like to acknowledge André Seixas Pereira for all the assistance with figures and graphs.

\section{REFERENCES}

[1] Bulbake U, Doppalapudi S, Kommineni N, Khan W. Liposomal formulations in clinical use: An updated review. Pharmaceutics 2017; 9(2)

[2] Napoli C, Lemieux C, Jorgensen R. Introduction of a chimeric chalcone synthase gene into petunia results in reversible cosuppression of homologous genes in trans. Plant Cell 1990; 2(4): 279-89.

[3] Romano N, Macino G. Quelling: Transient inactivation of gene expression in neurospora crassa by transformation with homologous sequences. Mol Microbiol 1992; 6(22): 3343-53.

[4] Guo S, Kemphues KJ. Par-1, a gene required for establishing polarity in c. Elegans embryos, encodes a putative ser/thr kinase that is asymmetrically distributed. Cell 1995; 81(4): 611-20.

[5] Fire A, Xu S, Montgomery MK, Kostas SA, Driver SE, Mello CC Potent and specific genetic interference by double-stranded rna in caenorhabditis elegans. Nature 1998; 391(6669): 806-11.

[6] Elbashir SM, Harborth J, Lendeckel W, Yalcin A, Weber K, Tuschl T. Duplexes of 21-nucleotide rnas mediate rna interference in cultured mammalian cells. Nature 2001; 411(6836): 494-8.

[7] McCaffrey AP, Meuse L, Pham TT, Conklin DS, Hannon GJ, Kay MA. Rna interference in adult mice. Nature 2002; 418(6893): 38-9.

[8] Wu SY, Lopez-Berestein G, Calin GA, Sood AK. Targeting the undruggable: Advances and obstacles in current rnai therapy. Sci Transl Med 2014; 6(240): 1-15.

[9] Carroll JB, Warby SC, Southwell AL, et al. Potent and selective antisense oligonucleotides targeting single-nucleotide polymorphisms in the huntington disease gene / allele-specific silencing of mutant huntingtin. Mol Ther 2011; 19(12): 2178-2185.

[10] Wooddell CI, Rozema DB, Hossbach M, et al. Hepatocyte-targeted rnai therapeutics for the treatment of chronic hepatitis b virus infection. Mol Ther 2013; 21(5): 973-85.

[11] Oh YK, Park TG. Sirna delivery systems for cancer treatment. Adv Drug Deliv Rev 2009; 61(10): 850-62.

[12] Resnier P, Montier T, Mathieu V, Benoit JP, Passirani C. A review of the current status of sirna nanomedicines in the treatment of cancer. Biomaterials 2013; 34(27): 6429-43.

[13] Mendonca LS, Firmino F, Moreira JN, Pedroso de Lima MC, Simoes S. Transferrin receptor-targeted liposomes encapsulating antibcr-abl sirna or asodn for chronic myeloid leukemia treatment. Bioconjug Chem. 2010; 21(1): 157-168.

[14] Crombez L, Morris MC, Dufort S, et al. Targeting cyclin b1 through peptide-based delivery of sirna prevents tumour growth. Nucleic Acids Res 2009; 37(14): 4559-69.

[15] Sun TM, Du JZ, Yao YD, et al. Simultaneous delivery of sirna and paclitaxel via a "two-in-one" micelleplex promotes synergistic tumor suppression. ACS Nano 2011; 5(2): 1483-94. 
[16] Yang XZ, Dou S, Sun TM, Mao CQ, Wang HX, Wang J. Systemic delivery of sirna with cationic lipid assisted peg-pla nanoparticles for cancer therapy. J Control Release 2011; 156(2): 203-11.

[17] Kaestner P, Aigner A, Bastians H. Therapeutic targeting of the mitotic spindle checkpoint through nanoparticle-mediated sirna delivery inhibits tumor growth in vivo. Cancer Lett 2011; 304(2): 128-36.

[18] Tanaka T, Mangala LS, Vivas-Mejia PE, et al. Sustained small interfering rna delivery by mesoporous silicon particles. Cancer Res 2010; 70(9): 3687-96.

[19] Sasaki T, Nakashiro K, Tanaka H, et al. Knockdown of akt isoforms by rna silencing suppresses the growth of human prostate cancer cells in vitro and in vivo. Biochem Biophys Res Commun 2010; 399(1): 79-83.

[20] Han HD, Mangala LS, Lee JW, et al. Targeted gene silencing using rgd-labeled chitosan nanoparticles. Clin Cancer Res 2010; 16(15): 3910-22.

[21] Sonoke S, Ueda T, Fujiwara K, et al. Tumor regression in mice by delivery of bcl-2 small interfering rna with pegylated cationic liposomes. Cancer Res 2008; 68(21): 8843-51.

[22] Mu P, Nagahara S, Makita N, Tarumi Y, Kadomatsu K, Takei Y. Systemic delivery of sirna specific to tumor mediated by atelocollagen: Combined therapy using sirna targeting bcl-xl and cisplatin against prostate cancer. Int J Cancer 2009; 125(12): 2978-90.

[23] Shim G, Han SE, Yu YH, et al. Trilysinoyl oleylamide-based cationic liposomes for systemic co-delivery of sirna and an anticancer drug. J Control Release 2011; 155(1): 60-6.

[24] Xue HY, Wong HL. Solid lipid-pei hybrid nanocarrier: An integrated approach to provide extended, targeted, and safer sirna therapy of prostate cancer in an all-in-one manner. ACS Nano. 2011; 5(9): 7034-47.

[25] Kim SH, Jeong JH, Lee SH, Kim SW, Park TG. Local and systemic delivery of vegf sirna using polyelectrolyte complex micelles for effective treatment of cancer. J Control Release 2008; 129(2): 107-16.

[26] Guo J, Cheng WP, Gu J, et al. Systemic delivery of therapeutic small interfering rna using a ph-triggered amphiphilic poly-l-lysine nanocarrier to suppress prostate cancer growth in mice. Eur $\mathbf{J}$ Pharm Sci 2012; 45(5): 521-32.

[27] Villares GJ, Zigler M, Blehm K, et al. Targeting egfr in bladder cancer. World J Urol 2007; 25(6): 573-9.

[28] Aleku M, Schulz P, Keil O, et al. Atu027, a liposomal small interfering rna formulation targeting protein kinase $\mathrm{n} 3$, inhibits cancer progression. Cancer Res 2008; 68(23): 9788-98.

[29] Yagi N, Manabe I, Tottori T, et al. A nanoparticle system specifically designed to deliver short interfering rna inhibits tumor growth in vivo. Cancer Res 2009; 69(16): 6531-8

[30] Panneer Selvam S, De Palma RM, Oaks JJ, et al. Binding of the sphingolipid s1p to htert stabilizes telomerase at the nuclear periphery by allosterically mimicking protein phosphorylation. Sci Signal 2015; 8(381): ra58.

[31] Wu SY, Singhania A, Burgess M, et al. Systemic delivery of e6/7 sirna using novel lipidic particles and its application with cisplatin in cervical cancer mouse models. Gene Ther 2011; 18(1): 14-22.

[32] Hu-Lieskovan S, Heidel JD, Bartlett DW, Davis ME, Triche TJ. Sequence-specific knockdown of ews-flil by targeted, nonviral delivery of small interfering rna inhibits tumor growth in a murine model of metastatic ewing's sarcoma. Cancer Res 2005; 65(19): 8984-92.

[33] Monia BP, Johnston JF, Geiger T, Muller M, Fabbro D. Antitumor activity of a phosphorothioate antisense oligodeoxynucleotide targeted against c-raf kinase. Nat Med 1996; 2(6): 668-75.

[34] Li SD, Chono S, Huang L. Efficient oncogene silencing and metastasis inhibition via systemic delivery of sirna. Mol Ther 2008; 16(5): 942-6.

[35] Zaree Mahmodabady A, Javadi HR, Kamali M, Najafi A, Hojati Z. Bcr-abl silencing by specific small-interference rna expression vector as a potential treatment for chronic myeloid leukemia. Iran Biomed J 2010; 14(1-2): 1-8.

[36] Wu H, Hait WN, Yang JM. Small interfering rna-induced suppression of mdr1 (p-glycoprotein) restores sensitivity to multidrugresistant cancer cells. Cancer Res 2003; 63(7): 1515-9.

[37] Wilson RC, Doudna JA. Molecular mechanisms of rna interference. Annu Rev Biophys 2013; 42: 217-39.

[38] Sioud M. Rna interference: Mechanisms, technical challenges, and therapeutic opportunities. Methods Mol Biol 2015; 1218: 1-15.
[39] Zeng Y. Principles of micro-rna production and maturation. Oncogene. 2006; 25 (46): 6156-62.

[40] Macrae IJ, Zhou K, Li F, et al. Structural basis for double-stranded rna processing by dicer. Science 2006; 311(5758): 195-8.

[41] Carthew RW, Sontheimer EJ. Origins and mechanisms of mirnas and sirnas. Cell 2009; 136(4): 642-655.

[42] Ipsaro JJ, Joshua-Tor L. From guide to target: Molecular insights into eukaryotic rna-interference machinery. Nat Struct Mol Biol 2015; 22(1): 20-8.

[43] Tomari Y, Zamore PD. Perspective: Machines for rnai. Genes Dev 2005; 19(5): 517-529.

[44] Castanotto D, Sakurai K, Lingeman R, et al. Combinatorial delivery of small interfering rnas reduces rnai efficacy by selective incorporation into risc. Nucleic Acids Res 2007; 35(15): 5154-64.

[45] Behlke MA. Chemical modification of sirnas for in vivo use. Oligonucleotides 2008; 18(4): 305-19.

[46] Jackson AL, Linsley PS. Recognizing and avoiding sirna off-target effects for target identification and therapeutic application. Nat Rev Drug Discov 2010; 9(1): 57-67.

[47] Westerhout EM, Ooms M, Vink M, Das AT, Berkhout B. Hiv-1 can escape from rna interference by evolving an alternative structure in its rna genome. Nucleic Acids Res 2005; 33(2): 796-804.

[48] Gao K, Huang L. Achieving efficient rnai therapy: Progress and challenges. Acta Pharma Sin B 2013; 3(4): 213-25.

[49] Bennett CF, Swayze EE. Rna targeting therapeutics: Molecular mechanisms of antisense oligonucleotides as a therapeutic platform. Annu Rev Pharmacol Toxicol 2010; 50 259-93.

[50] Layzer JM, McCaffrey AP, Tanner AK, Huang Z, Kay MA, Sullenger BA. In vivo activity of nuclease-resistant sirnas. RNA 2004; 10(5): 766-71.

[51] Ozcan G, Ozpolat B, Coleman RL, Sood AK, Lopez-Berestein G. Preclinical and clinical development of sirna-based therapeutics. Adv Drug Deliv Rev 2015; 87 108-19.

[52] Kim TK, Eberwine JH. Mammalian cell transfection: The present and the future. Anal Bioanal Chem 2010; 397(8): 3173-8.

[53] Gojo S, Yamamoto S, Patience C, LeGuern C, Cooper DK. Gene therapy--its potential in surgery. Ann R Coll Surg Engl 2002; 84(5): 297-301.

[54] Burnett JC, Rossi JJ, Tiemann K. Current progress of sirna/shrna therapeutics in clinical trials. Biotechnol J 2011; 6(9): 1130-46.

[55] Vannucci L, Lai M, Chiuppesi F, Ceccherini-Nelli L, Pistello M. Viral vectors: A look back and ahead on gene transfer technology. New Microbiol 2013; 36(1): 1-22.

[56] Ibraheem D, Elaissari A, Fessi H. Gene therapy and DNA delivery systems. Int J Pharm 2014; 459(1-2): 70-83.

[57] Soutschek J, Akinc A, Bramlage B, et al. Therapeutic silencing of an endogenous gene by systemic administration of modified sirnas. Nature 2004; 432(7014): 173-178.

[58] Nishina K, Unno T, Uno Y, et al. Efficient in vivo delivery of sirna to the liver by conjugation of alpha-tocopherol. Mol Ther 2008; 16(4): 734-40.

[59] Moschos SA, Jones SW, Perry MM, et al. Lung delivery studies using sirna conjugated to tat(48-60) and penetratin reveal peptide induced reduction in gene expression and induction of innate immunity. Bioconjug Chem 2007; 18(5): 1450-9.

[60] Kim SH, Jeong JH, Lee SH, Kim SW, Park TG. Peg conjugated vegf sirna for anti-angiogenic gene therapy. J Control Release 2006; 116(2): 123-9.

[61] Chu TC, Twu KY, Ellington AD, Levy M. Aptamer mediated sirna delivery. Nucleic Acids Res 2006; 34(10): e73.

[62] Zhao E, Zhao Z, Wang J, et al. Surface engineering of gold nanoparticles for in vitro sirna delivery. Nanoscale 2012; 4(16): 5102-9.

[63] Jiang S, Eltoukhy AA, Love KT, Langer R, Anderson DG. Lipidoid-coated iron oxide nanoparticles for efficient DNA and sirna delivery. Nano Lett 2013; 13(3): 1059-64.

[64] Zhang Z, Yang X, Zhang Y, et al. Delivery of telomerase reverse transcriptase small interfering rna in complex with positively charged single-walled carbon nanotubes suppresses tumor growth. Clin Cancer Res. 2006; 12(16): 4933-9.

[65] Liu P, Yu H, Sun Y, Zhu M, Duan Y. A mpeg-plga-b-pll copolymer carrier for adriamycin and sirna delivery. Biomaterials 2012; 33(17): 4403-12.

[66] Howard KA, Rahbek UL, Liu X, et al. Rna interference in vitro and in vivo using a novel chitosan/sirna nanoparticle system. Mol Ther 2006; 14(4): 476-84. 
[67] Patil ML, Zhang M, Taratula O, Garbuzenko OB, He H, Minko T. Internally cationic polyamidoamine pamam-oh dendrimers for sirna delivery: Effect of the degree of quaternization and cancer targeting. Biomacromolecules. 2009; 10(2): 258-66.

[68] Giner-Casares JJ, Henriksen-Lacey M, Coronado-Puchau M, LizMarzán LM. Inorganic nanoparticles for biomedicine: Where materials scientists meet medical research. Materials Today 2016; 19(1): $19-28$.

[69] Tatiparti K, Sau S, Kashaw S, KIyer AK. Sirna delivery strategies: A comprehensive review of recent developments. Nanomaterials (Basel). 2017; 7(4): pii: E77.

[70] Ojea-Jimenez I, Comenge J, Garcia-Fernandez L, Megson ZA, Casals E, Puntes VF. Engineered inorganic nanoparticles for drug delivery applications. Curr Drug Metab 2013; 14(5): 518-30.

[71] Kim T, Hyeon T. Applications of inorganic nanoparticles as therapeutic agents. Nanotechnology 2014; 25(1): 012001.

[72] Ghosh P, Han G, De M, Kim CK, Rotello VM. Gold nanoparticles in delivery applications. Adv Drug Deliv Rev. 2008; 60(11): 130715.

[73] Wu W, Wu Z, Yu T, Jiang C, Kim WS. Recent progress on magnetic iron oxide nanoparticles: Synthesis, surface functional strategies and biomedical applications. Sci Technol Adv Mater 2015; 16(2): 023501.

[74] Liu Z, Tabakman S, Welsher K, Dai H. Carbon nanotubes in biology and medicine: In vitro and in vivo detection, imaging and drug delivery. Nano Res 2009; 2(2): 85-120.

[75] Soenen SJ, Rivera-Gil P, Montenegro JM, Parak WJ, De Smedt SC, Braeckmans K. Cellular toxicity of inorganic nanoparticles: Common aspects and guidelines for improved nanotoxicity evaluation. NannoToday 2011; 6(5): 446-65.

[76] Wang Y, Ding L, Yao C, et al. Toxic effects of metal oxide nanoparticles and their underlying mechanisms. Science China Materials 2017; 60(2): 93-108.

[77] Saraswathy M, Gong S. Recent developments in the co-delivery of sirna and small molecule anticancer drugs for cancer treatment. Biochem. Pharmacol 2014; 17(6): 298-306.

[78] Bangham AD, Standish MM, Watkins JC. Diffusion of univalent ions across the lamellae of swollen phospholipids. J Mol Biol 1965; 13(1): 238-52.

[79] Gregoriadis G. Drug entrapment in liposomes. FEBS Lett 1973; 36(3): 292-6.

[80] Jin S, Ye K. Nanoparticle-mediated drug delivery and gene therapy. Biotechnol Prog 2007; 23(1): 32-41.

[81] Laouini A, Jaafar-Maalej C, Limayem-Blouza I, Sfar S, Charcosset C, Fessi H. Preparation, characterization and applications of liposomes: State of the art. J Colloid Sci Biotechnol 2012; 1(2): 147-68.

[82] Felgner PL, Gadek TR, Holm M, et al. Lipofection: A highly efficient, lipid-mediated DNA-transfection procedure. Proc Natl Acad Sci U S A 1987; 84(21): 7413-7417.

[83] Sun H, Yarovoy I, Capeling M, Cheng C. Polymers in the codelivery of sirna and anticancer drugs for the treatment of drugresistant cancers. Top Curr Chem (Cham) 2017; 375(2): 24.

[84] Koynova R, Tenchov B. Cationic lipids: Molecular structure/ transfection activity relationships and interactions with biomembranes. Top Curr Chem 2010; 296 51-93.

[85] Lv H, Zhang S, Wang B, Cui S, Yan J. Toxicity of cationic lipids and cationic polymers in gene delivery. J Control Release 2006; 114(1): 100-109.

[86] Karmali PP, Chaudhuri A. Cationic liposomes as non-viral carriers of gene medicines: Resolved issues, open questions, and future promises. Med Res Rev 2007; 27(5): 696-722.

[87] Koltover I, Salditt T, Radler JO, Safinya CR. An inverted hexagonal phase of cationic liposome-DNA complexes related to DNA release and delivery. Science 1998; 281(5373): 78-81.

[88] Zuhorn IS, Bakowsky U, Polushkin E, et al. Nonbilayer phase of lipoplex-membrane mixture determines endosomal escape of genetic cargo and transfection efficiency. Mol Ther 2005; 11(5): 801810 .

[89] Zuidam NJ, Barenholz Y. Electrostatic and structural properties of complexes involving plasmid DNA and cationic lipids commonly used for gene delivery. Biochim Biophys Acta 1998; 1368(1): 115128.

[90] Balazs DA, Godbey W. Liposomes for use in gene delivery. J Drug Deliv. 2011; 2011326497.
[91] Oliveira AC, Sárria MP, Moreira P, et al. Counter ions and constituents combination affect dodax: Mo nanocarriers toxicity in vitro and in vivo. Toxicology research 2016; 5(4): 1244-1255.

[92] Hungerford G, Castanheira EM, Baptista AL, Coutinho PJ, Oliveira ME. Domain formation in dodab-cholesterol mixed systems monitored via nile red anisotropy. J Fluoresc 2005; 15(6): 835-840.

[93] Misra SK, Biswas J, Kondaiah P, Bhattacharya S. Gene transfection in high serum levels: Case studies with new cholesterol based cationic gemini lipids. PLoS One 2013; 8(7): e68305.

[94] Nguyen VH, Lee BJ. Protein corona: A new approach for nanomedicine design. Int J Nanomedicine 2017; 12: 3137-51.

[95] Betker JL, Gomez J, Anchordoquy TJ. The effects of lipoplex formulation variables on the protein corona and comparisons with in vitro transfection efficiency. J Control Release 2013; 171(3): 261-8.

[96] Sternberg B, Hong K, Zheng W, Papahadjopoulos D. Ultrastructural characterization of cationic liposome-DNA complexes showing enhanced stability in serum and high transfection activity in vivo. Biochim Biophys Acta. 1998; 1375(1-2): 23-35.

[97] Faneca H, Simoes S, de Lima MC. Evaluation of lipid-based reagents to mediate intracellular gene delivery. Biochim Biophys Acta. 2002; 1567(1-2): 23-33.

[98] Silva JP, Oliveira AC, Casal MP, et al. Dodab:Monoolein-based lipoplexes as non-viral vectors for transfection of mammalian cells. Biochim Biophys Acta 2011; 1808(10): 2440-9.

[99] Silva JP, Oliveira ACN, Gomes AC, et al. (2012). Development of Dioctadecyldimethylammonium Bromide/Monoolein Liposomes for Gene Delivery, Cell Interaction, Sivakumar Gowder (Ed.), ISBN: 978-953-51-0792-7.

[100] Oliveira AC, Martens TF, Raemdonck K, et al. Dioctadecyldimethylammonium:Monoolein nanocarriers for efficient in vitro gene silencing. ACS Appl Mater Interfaces 2014; 6(9): 6977-6989.

[101] Luzzati V. Biological significance of lipid polymorphism: The cubic phases. Curr Opin Struct Biol 1997; 7(5): 661-668.

[102] Desigaux L, Sainlos M, Lambert O, et al. Self-assembled lamellar complexes of sirna with lipidic aminoglycoside derivatives promote efficient sirna delivery and interference. Proc Natl Acad Sci U S A 2007 ; 104(42): 16534-9.

[103] Weisman S, Hirsch-Lerner D, Barenholz Y, Talmon Y. Nanostructure of cationic lipid-oligonucleotide complexes. Biophys J. 2004; 87(1): 609-614.

[104] Huebner S, Battersby BJ, Grimm R, Cevc G. Lipid-DNA complex formation: Reorganization and rupture of lipid vesicles in the presence of DNA as observed by cryoelectron microscopy. Biophys $\mathrm{J}$ 1999; 76(6): 3158-66.

[105] Ciani L, Ristori S, Bonechi C, Rossi C, Martini G. Effect of the preparation procedure on the structural properties of oligonucleotide/cationic liposome complexes (lipoplexes) studied by electron spin resonance and zeta potential. Biophys Chem 2007; 131(1-3): 80-7.

[106] Wang T, Upponi JR, Torchilin VP. Design of multifunctional nonviral gene vectors to overcome physiological barriers: Dilemmas and strategies. Int J Pharm 2012; 427(1): 3-20.

[107] Gabizon A, Papahadjopoulos D. Liposome formulations with prolonged circulation time in blood and enhanced uptake by tumors. Proc Natl Acad Sci U S A. 1988; 85(18): 6949-53.

[108] Allen TM, Hansen C, Martin F, Redemann C, Yau-Young A. Liposomes containing synthetic lipid derivatives of poly(ethylene glycol) show prolonged circulation half-lives in vivo. Biochim Biophys Acta 1991; 1066(1): 29-36.

[109] Hama S, Itakura S, Nakai M, et al. Overcoming the polyethylene glycol dilemma via pathological environment-sensitive change of the surface property of nanoparticles for cellular entry. J Control Release 2015; 206: 67-74.

[110] Hattori Y, Nakamura A, Arai S, Kawano K, Maitani Y, Yonemochi E. Sirna delivery to lung-metastasized tumor by systemic injection with cationic liposomes. J Liposome Res 2015; 25(4): 279-86.

[111] Dar GH, Gopal V, Rao NM. Systemic delivery of stable sirnaencapsulating lipid vesicles: Optimization, biodistribution, and tumor suppression. Mol Pharm 2015; 12(2): 610-20.

[112] Nogueira E, Freitas J, Loureiro A, et al. Neutral pegylated liposo$\mathrm{mal}$ formulation for efficient folate-mediated delivery of mcll sirna to activated macrophages. Colloids Surf B Biointerfaces 2017; 155: 459-65.

[113] Pietralik Z, Kolodziejska Z, Weiss M, Kozak M. Gemini surfactants based on bis-imidazolium alkoxy derivatives as effective 
agents for delivery of nucleic acids: A structural and spectroscopic study. PLoS One 2015; 10(12): e0144373.

[114] Cruz RQ, Morais CM, Cardoso AM, et al. Enhancing glioblastoma cell sensitivity to chemotherapeutics: A strategy involving survivin gene silencing mediated by gemini surfactant-based complexes. Eur J Pharm Biopharm. 2016; 104 7-18.

[115] Kapoor M, Burgess DJ. Efficient and safe delivery of sirna using anionic lipids: Formulation optimization studies. Int J Pharm 2012; 432(1-2): 80-90.

[116] Oliveira AC, Raemdonck K, Martens T, et al. Stealth monooleinbased nanocarriers for delivery of sirna to cancer cells. Acta Biomater 2015; 25 216-229.

[117] Gao J, Yu Y, Zhang Y, et al. Egfr-specific pegylated immunoliposomes for active sirna delivery in hepatocellular carcinoma. Biomaterials 2012; 33(1): 270-282.

[118] Maeda H, Wu J, Sawa T, Matsumura Y, Hori K. Tumor vascular permeability and the epr effect in macromolecular therapeutics: A review. J Control Release 2000; 65(1-2): 271-84.

[119] Romberg B, Hennink WE, Storm G. Sheddable coatings for longcirculating nanoparticles. Pharm Res 2008; 25(1): 55-71.

[120] Immordino ML, Dosio F, Cattel L. Stealth liposomes: Review of the basic science, rationale, and clinical applications, existing and potential. Int J Nanomedicine 2006; 1(3): 297-315.

[121] Allen C, Dos Santos N, Gallagher R, et al. Controlling the physical behavior and biological performance of liposome formulations through use of surface grafted poly(ethylene glycol). Biosci Rep 2002; 22(2): 225-250.

[122] Li SD, Huang L. Nanoparticles evading the reticuloendothelial system: Role of the supported bilayer. Biochim Biophys Acta 2009; 1788(10): 2259-66.

[123] Braeckmans K, Buyens K, Bouquet W, et al. Sizing nanomatter in biological fluids by fluorescence single particle tracking. Nano Lett 2010; 10(11): 4435-42.

[124] Dakwar GR, Zagato E, Delanghe J, et al. Colloidal stability of nano-sized particles in the peritoneal fluid: Towards optimizing drug delivery systems for intraperitoneal therapy. Acta Biomater 2014; 10(7): 2965-2975.

[125] Buyens K, Lucas B, Raemdonck K, et al. A fast and sensitive method for measuring the integrity of sirna-carrier complexes in full human serum. J Control Release 2008; 126(1): 67-76.

[126] Shi F, Wasungu L, Nomden A, et al. Interference of poly(ethylene glycol)-lipid analogues with cationic-lipid-mediated delivery of oligonucleotides; role of lipid exchangeability and non-lamellar transitions. Biochem J 2002; 366(Pt 1): 333-41.

[127] Hafez IM, Maurer N, Cullis PR. On the mechanism whereby cationic lipids promote intracellular delivery of polynucleic acids. Gene Ther 2001; 8(15): 1188-96.

[128] Sewell SL, Giorgio TD. Synthesis and enzymatic cleavage of dualligand quantum dots. Materials Science and Engineering: C. 2009; 29(4): 1428-32.

[129] Rejman J, Wagenaar A, Engberts JB, Hoekstra D. Characterization and transfection properties of lipoplexes stabilized with novel exchangeable polyethylene glycol-lipid conjugates. Biochim Biophys Acta 2004; 1660(1-2): 41-52.

[130] Buyens K, De Smedt SC, Braeckmans K, et al. Liposome based systems for systemic sirna delivery: Stability in blood sets the requirements for optimal carrier design. J Control Release 2012; 158(3): 362-70.

[131] Rehman ZU, Zuhorn IS, Hoekstra D. How cationic lipids transfer nucleic acids into cells and across cellular membranes: Recent advances. J Control Release 2013; 166(1): 46-56.

[132] Daniels TR, Bernabeu E, Rodriguez JA, et al. The transferrin receptor and the targeted delivery of therapeutic agents against cancer. Biochim Biophys Acta 2012; 1820(3): 291-317.

[133] Xiang S, Tong H, Shi Q, et al. Uptake mechanisms of non-viral gene delivery. J Control Release 2012; 158(3): 371-8

[134] Sahay G, Alakhova DY, Kabanov AV. Endocytosis of nanomedicines. J Control Release 2010; 145(3): 182-95.

[135] Young SW, Stenzel M, Yang JL. Nanoparticle-sirna: A potential cancer therapy? Crit Rev Oncol Hematol 2016; 98 159-69.

[136] Ulrich AS. Biophysical aspects of using liposomes as delivery vehicles. Biosci Rep 2002; 22(2): 129-150.

[137] Zelphati O, Szoka FC. Mechanism of oligonucleotide release from cationic liposomes. Proc Natl Acad Sci U S A 1996; 93(21): 11493-8.
[138] Farhood H, Serbina N, Huang L. The role of dioleoyl phosphatidylethanolamine in cationic liposome mediated gene transfer. Biochim Biophys Acta 1995; 1235(2): 289-295.

[139] Obata Y, Tajima S, Takeoka S. Evaluation of ph-responsive liposomes containing amino acid-based zwitterionic lipids for improving intracellular drug delivery in vitro and in vivo. J Control Release 2010; 142(2): 267-76.

[140] Kumar VV, Pichon C, Refregiers M, Guerin B, Midoux P, Chaudhuri A. Single histidine residue in head-group region is sufficient to impart remarkable gene transfection properties to cationic lipids: Evidence for histidine-mediated membrane fusion at acidic ph. Gene Ther 2003; 10(15): 1206-15.

[141] Cho YW, Kim JD, Park K. Polycation gene delivery systems: Escape from endosomes to cytosol. J Pharm Pharmacol. 2003; 55(6): 721-34.

[142] Murphy EA, Majeti BK, Barnes LA, et al. Nanoparticle-mediated drug delivery to tumor vasculature suppresses metastasis. Proc Natl Acad Sci U S A 2008; 105(27): 9343-8.

[143] Lu RM, Chang YL, Chen MS, Wu HC. Single chain anti-c-met antibody conjugated nanoparticles for in vivo tumor-targeted imaging and drug delivery. Biomaterials 2011; 32(12): 3265-74.

[144] Yoshizawa T, Hattori Y, Hakoshima M, Koga K, Maitani Y. Folate-linked lipid-based nanoparticles for synthetic sirna delivery in kb tumor xenografts. Eur J Pharm Biopharm 2008; 70(3): 718-25.

[145] Li L, Hou J, Liu X, et al. Nucleolin-targeting liposomes guided by aptamer as 1411 for the delivery of sirna for the treatment of malignant melanomas. Biomaterials 2014; 35(12): 3840-50.

[146] Simoes S, Slepushkin V, Pires P, Gaspar R, de Lima MP, Duzgunes N. Mechanisms of gene transfer mediated by lipoplexes associated with targeting ligands or ph-sensitive peptides. Gene Ther 1999; 6(11): 1798-1807.

[147] Yang C, Zhang C, Zhao Z, Zhu T, Yang B. Fighting against kidney diseases with small interfering rna: Opportunities and challenges. $\mathrm{J}$ Transl Med 2015; 13: 39.

[148] Curtin JF, Candolfi M, Xiong W, Lowenstein PR, Castro MG. Turning the gene tap off; implications of regulating gene expression for cancer therapeutics. Mol Cancer Ther 2008; 7(3): 439-48.

[149] Youn H, Chung JK. Modified mrna as an alternative to plasmid DNA(pdna) for transcript replacement and vaccination therapy. Expert Opin Biol Ther 2015; 15(9): 1337-48.

[150] Morrissey DV, Lockridge JA, Shaw L, et al. Potent and persistent in vivo anti-hbv activity of chemically modified sirnas. Nat Biotechnol 2005; 23(8): 1002-7.

[151] Meng Z, Lu M. Rna interference-induced innate immunity, offtarget effect, or immune adjuvant? Front Immunol 2017; 8: 331.

[152] Corey DR. Chemical modification: The key to clinical application of rna interference? J Clin Invest 2007; 117(12): 3615-22.

[153] Wittrup A, Lieberman J. Knocking down disease: A progress report on sirna therapeutics. Nat Rev Genet 2015; 16(9): 543-552.

[154] Kanasty R, Dorkin JR, Vegas A, Anderson D. Delivery materials for sirna therapeutics. Nat Mater 2013; 12(11): 967-77.

[155] Coelho T, Adams D, Silva A, et al. Safety and efficacy of rnai therapy for transthyretin amyloidosis. N Engl J Med 2013; 369(9): 819-29.

[156] Kaczmarek JC, Kowalski PS, Anderson DG. Advances in the delivery of rna therapeutics: From concept to clinical reality. Genome Med 2017; 9(1): 60.

[157] Silva JPN, Real Oliveira MECD, Coutinho PJG. Characterization of mixed dodab/monoolein aggregates using nile red as a solvatochromic and anisotropy fluorescent probe. J Photochem Photobiol A Chem 2009; 203(1): 32-39.

[158] Silva JP, Oliveira IM, Oliveira AC, et al. Structural dynamics and physicochemical properties of pdna/dodab:Mo lipoplexes: Effect of ph and anionic lipids in inverted non-lamellar phases versus lamellar phases. Biochim Biophys Acta 2014; 1838(10): 2555-67.

[159] Oliveira IM, Silva JP, Feitosa E, Marques EF, Castanheira EM Real Oliveira MECD. Aggregation behavior of aqueous dioctadecyldimethylammonium bromide/monoolein mixtures: A multitechnique investigation on the influence of composition and temperature. J Colloid Interface Sci 2012; 374(1): 206-17.

[160] Carneiro C, Correia A, Collins T, et al. Dodab:Monoolein liposomes containing candida albicans cell wall surface proteins: A novel adjuvant and delivery system. Eur J Pharm Biopharm 2015; 89: 190-200. 
[161] Neves Silva JP, Coutinho PJ, Real Oliveira MECD. Characterization of monoolein-based lipoplexes using fluorescence spectroscopy. J Fluoresc 2008; 18(2): 555-62.

[162] Silva JP, Oliveira AC, Lucio M, Gomes AC, Coutinho PJ, Real Oliveira MECD. Tunable pdna/dodab:Mo lipoplexes: The effect of incubation temperature on pdna/dodab:Mo lipoplexes structure and transfection efficiency. Colloids Surf B Biointerfaces 2014; 121: 371-9.

[163] Silva JPN, Oliveira ACN, Lúcio M, Gomes AFC, Real Oliveira MECD. How multi-step versus one-step preparation method affects the physicochemical properties and transfection efficiency of DNA/dodab:Mo lipoplexes. J Appl Solut Chem Model 2014; 3(2):

[164] Lopes I, A CNO, M PS, et al. Monoolein-based nanocarriers for enhanced folate receptor-mediated rna delivery to cancer cells. J Liposome Res 2016; 26(3): 199-210.

[165] Feitosa E, Barreleiro PC, Olofsson G. Phase transition in dioctadecyldimethylammonium bromide and chloride vesicles prepared by different methods. Chem Phys Lipids 2000; 105(2): 201-13.

[166] Feitosa E, Karlsson G, Edwards K. Unilamellar vesicles obtained by simply mixing dioctadecyldimethylammonium chloride and bromide with water. Chem Phys Lipids 2006; 140(12): 66-74.

[167] Feitosa E, Alves FR, Castanheira EMS, Real Oliveira MECD. Dodab and dodac bilayer-like aggregates in the micromolar surfac- tant concentration domain. Colloid and Polymer Science 2009; 287(5): 591-9.

[168] Feitosa E, Alves FR. The role of counterion on the thermotropic phase behavior of dodab and dodac vesicles. Chem Phys Lipids 2008; 156(1-2): 13-6.

[169] Liu CK, Warr GG. Hexagonal closest-packed spheres liquid crystalline phases stabilised by strongly hydrated counterions. Soft Matter 2014; 10(1): 83-7.

[170] Schulz PC, Rodriguez JL, Puig JE, Proverbio ZE. Phase behaviour of the dioctadecyldimethyl ammonium bromide - water system. J Therm Anal 1998; 51(1): 49-62.

[171] Ganem-Quintanar A, Quintanar-Guerrero D, Buri P. Monoolein: A review of the pharmaceutical applications. Drug Dev Ind Pharm 2000; 26(8): 809-20.

[172] Kulkarni CV, Wachter W, Iglesias-Salto G, Engelskirchen S, Ahualli S. Monoolein: A magic lipid? Phys Chem Chem Phys 2011; 13(8): 3004-21.

[173] Qiu H, Caffrey M. The phase diagram of the monoolein/water system: Metastability and equilibrium aspects. Biomaterials 2000; 21(3): 223-34.

[174] Real Oliveira MECD, Silva JPN, Coutinho PJG, Coutinho OMFP, Gomes AFC, Casal MPPA. Use of monoolein as a new auxiliary lipid for lipofection. 2015; WO2010/020935 1-15 